Western University

Scholarship@Western

Spring 4-2019

\title{
Mapping the Presence of Latin American Art in Canadian Museums and Universities
}

Alena Robin

arobin82@uwo.ca

Follow this and additional works at: https://ir.lib.uwo.ca/hispanicpub

Part of the Canadian History Commons, Cultural History Commons, History of Art, Architecture, and Archaeology Commons, Latin American History Commons, Latin American Languages and Societies Commons, and the Museum Studies Commons

Citation of this paper:

Robin, Alena, "Mapping the Presence of Latin American Art in Canadian Museums and Universities" (2019). Hispanic Studies Publications. 9.

https://ir.lib.uwo.ca/hispanicpub/9 


\title{
Mapping the Presence of Latin American Art in Canadian Museums and Universities
}

\begin{abstract}
ALENA ROBIN
ABSTRACT This essay overviews how Canadian museums and universities have historically accessioned Latin American visual culture and identifies potential ways of sustaining interest, streamlining initiatives, and promoting access. The larger project aims at contributing to a hemispheric and transnational understanding of the history and growth in Canada of the field of Latin American art and its subfields of Pre-Columbian, colonial, modern, and contemporary art. While the study of art history among Canadian museums and universities has kept up with the decades-long interest in Latin American art and visual culture, there remain considerable challenges in bringing Latin American art to the forefront of public consciousness. Despite the pioneering efforts of Canadian museums and universities, Latin American visual art remains largely unknown and underutilized. This essay advocates for better collaboration among institutions involved in Latin American visual art initiatives across Canada, and dialogue among these disparate stakeholders to establish underlying narratives.
\end{abstract}

KEY WORDS art, art history, Canada, collecting, exhibiting, Latin America, museums, teaching, universities, visual culture

RESUMEN Este ensayo busca ofrecer una visión general de cómo los museos y universidades canadienses han accedido históricamente a la cultura visual latinoamericana para identificar formas potenciales de mantener el interés, racionalizar iniciativas y promover el acceso. El objetivo del proyecto es contribuir a una comprensión hemisférica y transnacional de la historia y el crecimiento en Canadá del campo del arte latinoamericano y su subcampo del arte precolombino, colonial, moderno y contemporáneo. Si bien el estudio de la historia del arte entre los museos y las universidades canadienses ha seguido el paso del interés que ha habido en el arte y la cultura visual latinoamericanos durante décadas, sigue habiendo desafíos considerables para hacer que el arte latinoamericano ocupe un lugar de primera línea en la conciencia pública. A pesar de los esfuerzos pioneros de museos y universidades canadienses, el arte visual latinoamericano ha permanecido en gran parte desconocido e infrautilizado. Específicamente, este ensayo aboga por una mejor colaboración entre las instituciones canadienses que participan en iniciativas relacionadas con el arte visual de América Latina, y pretende alentar el diálogo entre estas diferentes partes interesadas para establecer narrativas comunes.

PALABRAS CLAVE América Latina, arte, Canadá, coleccionismo, cultura visual, enseñanza, exposición, historia del arte, museos, universidades

RESUMO Este ensaio procura fornecer uma visão geral de como os museus e universidades canadenses historicamente acessaram a cultura visual latino-americana a fim de identificar formas potenciais de manter o interesse, simplificar iniciativas e promover o acesso a ela. O projeto visa contribuir para uma compreensão hemisférica e transnacional da história e do crescimento no Canadá do campo da arte latino-americana e seus subcampos - arte pré-colombiana, colonial, moderna e contemporânea. Embora o estudo da história da arte entre os museus e universidades canadenses tenha acompanhado o interesse de décadas na arte e na cultura visual da América Latina, ainda existem desafios consideráveis para levar a arte latino-americana à vanguarda da consciência pública. Apesar dos esforços pioneiros dos museus e universidades canadenses, a arte visual latino-americana permaneceu em grande parte desconhecida e subutilizada. Especificamente, este ensaio defende uma melhor colaboração entre instituições envolvidas em iniciativas de arte visual latino-americanas em todo o Canadá, e o incentivo ao diálogo entre esses diferentes atores para estabelecer narrativas subjacentes.

PALAVRAS-Chave América Latina, Canadá, arte, colecionismo, cultura visual, ensino, exposições, história da arte, museus, universidades

In 194I, when Elizabeth Wilder extended "A Call for Pioneers," she was raising important issues in relation to the establishment of the study of Latin American art in the United States: only four colleges and universities, out of four hundred, reported courses dealing specifically with the subject. ${ }^{1}$ Why, she asked, are faculties of arts not urging

I wish to thank Evonne Levy for the inspiration to write this essay; María Laura Flores Barba, Ayelet Ishai, Iván Baruj Vázquez Clavellina,

Latin American and Latinx Visual Culture, Vol. I, Number 2, pp. 33-57. Electronic ISSN: 2576-0947 ( 2019 by The Regents of the University of California. All rights reserved. Please direct all requests for permission to photocopy or reproduce article content through the University of California Press's Reprints and Permissions web page, https://www.ucpress.edu/journals/reprints-permissions. DOI: https://doi.org/I0.1525/lavc.2019.120004 
their students into this field that is clearly in need of pioneers? She advised on the foundation of Latin American studies in arts departments, recommended the training of scholars, and advised institutions on the necessary materials for study, books for libraries, and photograph collections on the topic.

More than seventy years later, the panorama is quite different: the field of Latin American art is well established in the United States. Yet its growth was not constant. In 1988 Luis R. Cancel recalled his frustrations as an undergraduate in the early I970s, when he first wanted to learn more about his Puerto Rican heritage and contemporary Latin American art in general, and was unable to find any courses at the institutions he attended. As he emphasized, the implications were serious: if the most prestigious and influential art history departments in the country offered little, if any, exposure to artistic traditions south of the Rio Grande, this would affect the organization of museum exhibitions and publications on visual culture from this part of the world, and in turn would compromise "the ability of U.S. citizens to understand Latin American culture and society and to promote hemispheric cooperation." He thus embarked on a passionate mission, one he admitted was perhaps "too evangelical at times," to eliminate some of the obstacles he confronted. ${ }^{2}$

Fortunately there is now in the United States an abundance of scholars, museums, academic institutions, and fellowships dedicated to studying, collecting, exhibiting, researching, publishing, and educating audiences regarding the art of this region. But the situation is hardly comparable in Canada. ${ }^{3}$ Few Canadian museums with

and Christian Ylagan, research assistants from Western University, for their assistance during the first phase of this project; all the people who answered my queries; and Western University for its support through a Research Western Internal Research Programs Grant. Comments and suggestions from the anonymous readers and editors Charlene Villaseñor Black and Emily A. Engel have helped make this article much stronger. Much of my research was done online using university and museum web pages, which are (especially in the former case) subject to constant change. To save space I omit accessed-on dates for URLs, but assure readers that all information was current at the time of access in 2017-18.

I. Elizabeth Wilder, "Call for Pioneers," College Art Journal I, no. I (194I): 6-9.

2. Luis R. Cancel, "Introduction," in The Latin American Spirit: Art and Artists in the United States, 1920-1970 (New York: Bronx Museum of Art, 1988), 8, 9 .

3. It is interesting to note that there is a small presence of studies in the United Kingdom dealing with Latin American art, such as the articles included in the 2007 special issue of the Bulletin of Spanish Studies 84, nos. 4/5 (2007): Luis Rebaza-Soraluz, "The Study of Latin American Art in the UK: A Preliminary Note," 55I-55; Silvia Montes, "Beyond Multiculturalism: collections of Latin American art have studied them extensively. Insufficient scholarship has been devoted to analyzing the complex ideology behind temporary exhibitions of Latin American art in Canada. And nothing has been said so far about the pioneers of Latin American art in Canadian universities.

The purpose of this study is to overview the history and current state of Latin American art and art history in Canadian museums, galleries, and universities. Information on museum collections, exhibitions, and interest in Latin American art history at Canadian universities was gathered from numerous sources. I seek to contribute to a hemispheric and transnational understanding of the history and growth in Canada of the field of Latin American art and its subfields of Pre-Columbian, colonial, nineteenth-century, modern, and contemporary art. Some projects that claim to be transnational in nature overlook the Canadian situation, generalizing circumstances in the United States as "North American" without even questioning if things are different north of the border, exacerbating the "relative invisibility" of Canada in North American cultural circles. ${ }^{4} \mathrm{My}$ hope is to address and begin to fill this void. My project has

A Comparison of Latin American Art in Britain and the USA," 571-82; and Luis Rebaza-Soraluz, Dawn Ades, and Valerie Fraser, "The Beginnings of Latin American Art as a Subject of Academic Study in the UK: A Conversation," 557-69. Dawn Ades offers a comparative view of the situation in the United States and the United Kingdom in "Constructing Histories of Latin American Art," in The Two Art Histories: The Museum and the University, ed. Charles W. Haxthausen (Williamstown, MA: Sterling and Francine Art Institute, 2002): 32-44.

4. I am quoting from Mari Carmen Ramírez, "Brokering Identities: Art Curators and the Politics of Cultural Representation," in Thinking about Exhibitions, ed. Reesa Greenberg, Bruce W. Ferguson, Sandy Nairne (London: Routledge, 1996), I8 (e-book). But the same idea is found in the anthology of texts that "covers the whole American continent" but offers no mention of Canada: Gerardo Mosquera, ed., "Introduction," in Beyond the Fantastic: Contemporary Art Criticism from Latin America (London: Institute of International Visual Arts, 1995), 15. Again, the International Center for the Arts of the Americas (ICAA) pretends to collect, exhibit, research, and educate "audiences on the work of Latin American and Latino artists of the twentieth and twenty-first centuries," serving "the teaching and research needs of the academic and professional communities in the United States, Europe, and Latin America," but eliminates totally the presence of Canada in that equation. See Héctor Olea and Melina Kervandjian, eds., Resisting Categories: Latin American and/or Latino?, Critical Documents of 2oth-Century Latin American and Latino Art I (Houston: Museum of Fine Arts, International Center for the Arts of the Americas, 20I2), 20, 31. A similar reflection addresses the necessity for hemispheric dialogues, "theoretical exchange[,] and intellectual collaboration between the Americas" and mentions "North-South intersections," but again Canada is absent from the conversation: Tomás Ybarra-Frauto, "Latin American Culture and the United States in the New Millennium," in Collecting Latin American Art for the 2Ist Century, ed. Mari Carmen Ramírez and Theresa Papanikolas (Houston: Museum of Fine Arts, 2002), 55 . 
an ambitious scale, but it is not intended to be definitive; rather it aspires to stimulate further research and indicate directions for it. Although much new material is brought forth here, there still exists a substantial history worthy of continued investigation. Hopefully this study will serve as an incentive, and further research through individual case studies will provide a more definitive description of the state of Latin American art in Canada.

I invoke the term "art" in a totalizing way, including temporal and national fields, movements, and to some extent popular and ethnographic material. ${ }^{5}$ Although my usage might seem uncritical or monolithic, the idea is to encompass objects of visual and material culture from Latin America in Canada as a starting point. It is premature to establish the currency of the term in Canada-if it has its own contour or if the field has migrated north as conceptualized from the United States. I am not saying that Latin American art in Canada was conceived as isolated from the United States, but that Canada, like the United Kingdom, might have its own particular ways of understanding Latin American studies. Luis Rebaza-Soraluz refers to the British situation as an "ambiguous and sometimes conflictive interdependent relationship between the university systems on both sides of the Atlantic and their own particular ways of understanding Latin American Studies." Further compilation of data and analysis, case studies, and extensive dives in museum archives are necessary to ascertain whether there are trends or patterns peculiar to the Canadian situation in relation to Latin American art. Only then will we be able to consider the particularity of Latin American art's presence in Canada while acknowledging, as mentioned by Natalie Alvarez in relation to Latinx Canadian theater and performance, the "cross-border travels of cultural and critical traditions, as well as the transnational impacts of neocolonization, that require a framing of Canadian latinidad in a more expansive hemispheric topography."

I am aware of the limitations and problems that can arise from the totalizing term "Latin America," which

5. For more on this see Carolyn Dean, "The Trouble with (the Term) Art," Art Journal 65, no. 2 (2006): 24-32; Claire Farago, "Imagining Art History Otherwise," in Global and World Art in the Practice of the University Museum, ed. Jane Chin Davidson and Sandra Esslinger (London: Routledge, 2017), 115-30.

6. Rebaza-Soraluz, "The Study of Latin American Art in the UK," 554.

7. Natalie Alvarez, "Latina/o Canadian Theatre and Performance: Hemispheric Perspectives," in Latina/o Canadian Theatre and Performance, ed. Natalie Alvarez, New Essays on Canadian Theatre 3 (Toronto: Playwrights Canada, 2013), Iо. "pretends to encompass a multiplicity of stories within the singularity of the name." I certainly do not aspire to undermine Latin American cultural complexity. I use the concept instrumentally, to encompass with one umbrella term common historical and cultural affinities. There are many differences, but also sufficient points of contact to justify this approach.

In the first section of the essay I provide some general notions, challenges, and factors faced by Canadian museums and universities in improving the visibility, collection, and study of Latin American art and visual culture. I then briefly address the Latin American population in Canada and Canadian multiculturalism. Next I examine collections of Latin American art in Canada, temporary exhibitions of Latin American art in Canadian museums, and Latin American art history in Canadian universities. Lastly I offer some recommendations for the future of the field in the country.

\section{CANADIAN PERSPECTIVES ON LATIN AMERICAN ART}

Latin American art and visual culture have been part of the imaginaries of cultural institutions across Canada since the early twentieth century. The first donations to museum collections were at the beginning of the century; the first temporary exhibitions were organized in the early 1940s; and universities started hiring specialists in the field in the I970s. Over the years, these institutions seeking to promote and present Latin American art to their respective audiences have enjoyed varying degrees of success. Canadian museums and universities have administrated the collection, study, and public presentation of paintings, ceramics, and textiles from the Pre-Columbian period to contemporary times in ways that reflect their efforts to negotiate the historical and cultural complexity of those countries bound by a common past and categorized under the instrumental term Latin America.

The first factor that has made the study of Latin American art and visual culture in Canada challenging is its relatively late and decentralized beginnings. This put initial efforts toward its formal study at a disadvantage relative to other, more established fields in art history departments across the country, especially when compared to the

8. Monica Amor, "Cartographies: Exploring the Limitations of a Curatorial Paradigm," Third Text 8, nos. 28/29 (1994): 186. 
thriving situation of the field in the United States. ${ }^{9}$ Art history departments in Canada already operate at the crossroads of many academic traditions: French and English, due to the nation's colonial past, but also the US one, due to its geographical proximity. ${ }^{10}$ Despite the existence of a few well-known works and artists, Pre-Columbian and Hispanic art have mostly remained beyond the established canon of art history in Canada.

The second factor was the specific circumstances surrounding the arrival of Spanish-speaking immigrants to Canada. In the same way that the arrival of Spanish immigrants in Canada due to the Spanish Civil War had a strong impact on language and literature departments but not on art history departments, the first important wave of Latin American immigrants to Canada in the 1970 s was meaningful to other academic disciplines but not to visual culture. $^{11}$

The first exhibitions of Latin American art held in Canada in the 1940s treated the work mostly as a tool to strengthen political relations among nations. However, the increasing presence of Latin American people in Canada over the years became an impetus to reconsider those collections and exhibitions more positively. Just as the children of the first and second generations of Latin Americans in Canada now want to study and master the Spanish language, they also want to know more about their cultural roots. This shift in attitude reflects how promoting Latin American art for its aesthetic and cultural value can be beneficial to younger generations who are exposed to globalization now more than ever.

While Latin American art and visual culture have gained traction in several respects thanks to the efforts of Canadian museums and universities, Latin American art history has only a precarious foothold as a field of study. According to data gathered through the Art History in Canada Project, African, Islamic, and Latin American art remain the least

9. On the institutionalization of art history as a discipline in Canada see "Art History Project of Canada," Canada: A History of Art History, https:// arthistoryincanada.ca/.

Io. Laurier Lacroix, "L'histoire de l'art au Canada," Perspective: La revue de l'INHA 3 (2008): 476-500.

II. On this topic see Hugh Hazelton, Latinocanadá: A Critical Study of Ten Latin American Writers of Canada (Montreal: McGill-Queen's University Press, 2007), 3-27. As to the why of this, I am not yet sure. Perhaps art history departments are still relatively conservative and "canon" oriented, which would explain why Latin American artists and art historians coming to Canada in the 1970s did not much impact the discipline. The data has yet to be collected. represented among art history departments. ${ }^{12}$ This essay argues that the relative decentralization of collection efforts, the lack of an overarching narrative framework to guide visibility, and unstable stakeholder support are key challenges arising from the previously discussed factors that need to be addressed in order to secure the future of Latin American art and visual culture in Canada. I firmly believe that museums and universities must engage the current complexities of the Latin American art tradition in order to adequately address the continued rise of global immigration and desperately needed shifts away from the traditional Western canon. Limitations in institutional and material support cannot be allowed to impede improvement in the accessioning, institutionalization, and dissemination of Latin American art in Canada.

\section{LATIN AMERICANS IN CANADA}

Compared to the situation of its southern neighbor, the Latin American population in Canada is far less numerous, more recent, more diversified in terms of origins, and much less affected by aggressive discourse. As Victor Armony acknowledges, scholarship on the Latin American diaspora has enjoyed a long trajectory in the United States, whereas in Canada the situation tends to remain invisible, despite the proximity of the countries in question. ${ }^{13}$ And the US dynamics do not necessarily apply to the Canadian reality in terms of its offering to migrant populations social, political, economic, and cultural spaces in which integration and majority-minority relations evolve. In both countries, the situation is different in big cities versus smaller cities and rural areas, but in Canada there is the additional variable of the Anglophone provinces versus the French-speaking province of Québec. For example, Québec attracts twice as many Latin American immigrants

12. "Subjects of Art History," Canada: A History of Art History, https:// arthistoryincanada.ca/subjects/.

13. For this section I am indebted to Victor Armony, "Introduction: Latin American Diasporas: Common Origins and Different Paths," Canadian Ethnic Studies 46, no. 3 (2014): I-6; Victor Armony, "Latin American Communities in Canada: Trends in Diversity and Integration," Canadian Ethnic Studies 46, no. 3 (2014): 7-34; Victor Armony, "Les paradoxes d'une affinité culturelle: la construction de la diaspora latino-américaine au Québec," in Vues transversales. Panorama de la scène artistique latino-québécoise, ed. Mariza Gonzalez (Montreal: Éditions CIDIHCA/LatinArte, 2018), 21-39. Specifically on the Toronto Latin American diaspora see Luisa Veronis, “Strategic Spatial Essentialism: Latin Americans' Real and Imagined Geographies of Belonging in Toronto," Social and Cultural Geography 8, no. $3(2007): 455-73$. 
than the rest of Canada, presumably for reasons of "cultural affinities" such as the romance languages spoken and the importance of Catholicism.

Latin Americans in Canada have settled over several decades, since the late 1950s, in distinctive waves that correspond to different historical moments, reasons, and conditions of migration. ${ }^{14}$ The first important wave was from the 1970 s to the 1990s, when most Latin American immigrants came to Canada for political reasons, such as military dictatorships and civil wars, from South and Central America respectively. Since the mid-r990s most of the Latin American population admitted to Canada has arrived under the "economic category," that is, on the account of their prospective employability as skilled workers, a condition evaluated according to their level of education, work experience, and sufficient knowledge of Canadian official languages. ${ }^{15} \mathrm{~A}$ smaller number have come under the family reunification and refugee categories.

Several previous censuses from Statistics Canada have presented information on Latin American populations in Canada in a confusing way, in that the categories were not consistently comparable: sometimes under the rubric of "visible minority" (2006, 2001, 1996) or by place of birth (1986, 198I), while data from the 2016, 2011, and 1991 censuses reframed the demographic question by taking into account the language spoken at home. ${ }^{16}$ Given the data, a correspondence appears to exist between an increasing number of people who identify Spanish as their mother tongue and the positive engagement with Latin American art in provinces with bigger Spanish-speaking populations. ${ }^{17}$ This correspondence is evident in Ontario, Quebec,

14. Some scholars divide the waves with even greater specificity. See Luisa Veronis, "Immigrant Participation in the Transnational Era: Latin Americans' Experiences with Collective Organising in Toronto," International Migration and Integration II, no. 2 (2010): 177-78.

15. Armony, "Latin American Communities in Canada," 29. See also Luisa Veronis, "The Canadian Hispanic Day Parade, or How Latin American Immigrants Practise (Sub)urban Citizenship in Toronto," Environment and Planning A 38, no. 9 (2006): 1656.

16. To give one obvious example of why these data can lead to confusion: I speak Spanish at home, and I was born in Canada. And I have many friends who are Caucasian and were born in Latin America. "Visible minorities" are defined by the government as "persons, other than Aboriginal peoples, who are non-Caucasian in race or non-white in colour." See https://wwwi2.statcan. gc.ca/census-recensement/2016/ref/guides/006/98-500-x2016006-eng.cfm.

17. Data on Spanish as the mother tongue would read as follows on a national basis: 458,845 (2016), 410,670 (2011), 158,665 (1991). Total Latin American population by visible minority groups on a national basis: 304,245 (2006), 216,980 (2001), 176,970 (1996). Latin American population in Canada, by place of birth: 147,795 (1986), I17,555 (1981). According to the
British Columbia, and Alberta, which are not only the provinces with the highest concentrations of people of Latin American origin but also the provinces that tend to hire more Latin American specialists in art history departments, collect more Latin American artifacts, and host more Latin American art exhibitions. While there are many more conflating variables that go beyond the scope of this essay, these recent statistics highlight the undeniable impact of the presence of Latin American populations in Canada on cultural globalization at both the national and the regional level.

Although the national contexts are quite different, and the way of quantifying the diverse aspects of the populations on both sides of the border also reveals peculiar approaches and social realities, the diaspora's composition must be seen from a transnational perspective. By this I mean that the Latinx Canadian population should not be constructed in an isolated manner; it is not fashioned only through its interaction with Canadian society, but is part of a hemispheric situation. It has even been speculated by Victor Armony that the Latinx reality in the United States is so massively important that Canadian Latinxs will eventually gravitate toward the "US model of panethnicity" instead of creating a "different mode of diasporic identity. ${ }^{18}$ In particular, Armony addresses a divergence among Latin Americans in Quebec and the rest of Canada, hence the dualistic linguistic nature of Canada must be taken into account.

In the early 2000s, Luisa Veronis noted in her research on Latin American communities in Toronto that people referred to this immigrant population as an "orphan community" suffering from "social and spatial invisibility." ${ }^{19}$ The situation seems to have evolved since, at least on the art scene. A few galleries, such as Espacio Mexico in Montreal, Sur Gallery in Toronto, and initiatives by associations such as LatinArte have opened a necessary dialogue with the Latin American population through art, taking into account the artistic input of Latinx Canadian artists. At

2006 census, the provinces with highest concentrations of people of Latin American origins are Ontario (147,140), followed by Quebec $(89,510)$, British Columbia $(28,965)$, and Alberta $(27,265)$. According to the 2016 census, the provinces with highest numbers of Spanish speakers as their native tongue are Ontario (191,025), Quebec (145,635), Alberta (56,370) and British Columbia (47,010).

18. Armony, "Latin American Communities in Canada," 21.

19. Veronis, "Strategic Spatial Essentialism," 455; Veronis, "The Canadian Hispanic Day Parade," 1667. 
least one scholarly volume has been published that examines the presence of Latin American populations in Canada, specifically in Quebec, from different artistic disciplines. ${ }^{20}$

Furthermore, the Canadian model of multiculturalism, adopted as federal policy in 1971, valorizes cultural heritage and offers a welcoming context for identity affirmation. Respect for cultural diversity, equality, and antidiscrimination are core principles of multiculturalism, and were legally consolidated in 1988. Initially the goal was to ease French-English tensions-hence multiculturalism works within a bilingual framework to recognize both as equal "founding nations" - but it rapidly evolved to recognize and commend Canada's increasingly diverse ethnic groups and their contributions to national development. It eventually led to extensive facilities for the installation and integration of immigrants, and resources for the preservation of diverse cultures through festivals and language programs. ${ }^{21}$ In this sense, Canadian multiculturalism benefits Latinx Canadians, and art from Latin America has been an important tool in the equation.

\section{COLLECTING LATIN AMERICAN ART IN CANADA}

In general, major Canadian museum collections of Latin American art include abundant artifacts from the PreColumbian period, especially ceramics and textiles (Figures I-6). ${ }^{22}$ Various university museums across the country also hold smaller collections of Pre-Columbian artifacts, as is the case at the University of Alberta Museums, where the archaeological collection includes pottery and other material artifacts from past societies, while the ethnographic collection contains objects that relate to today's world and explore societies' beliefs and ways of living.

20. Gonzalez, Vues transversales.

21. For an overview of the history of Canadian multiculturalism see Stephen Tierney, ed., Multiculturalism and the Canadian Constitution (Vancouver: University of British Columbia Press, 2007). For an analysis of Canadian multiculturalism in relation to the Latin American community in Toronto see Veronis, “The Canadian Hispanic Day Parade," I653-7 I.

22. For this section of the project I relied heavily on websites of museums that showcase information on their collections; I also tried to contact curators to obtain more detailed information, but not all were equally receptive. I am convinced there is much more still to be discovered for museums that do not show all of their collections online. Another avenue pending exploration is that of private Canadian collectors of Latin American art. A number of museums whose collections may include artifacts not strictly considered "art" were taken into account, if they nonetheless educate the public about Latin American visual culture.

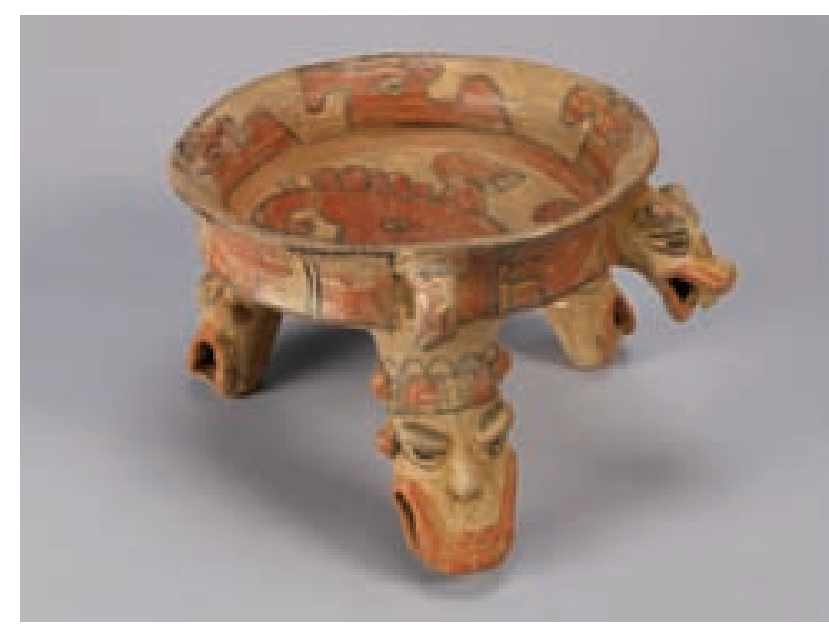

FIGURE 1. Unidentified artist, dish, Nicoya culture, Nicaragua, date unknown. Ceramic, $6 \times 8$ I/2 in. $(15.4 \times 21.7 \mathrm{~cm})$. Museum of Anthropology, Vancouver, donated by G. A. Hansen, 457/I a-b. Photo: Kyla Bailey, courtesy UBC Museum of Anthropology, Vancouver.

Another example of a university collection with a strong Pre-Columbian art focus is the Redpath Museum, attached to McGill University in Montreal, which has approximately six hundred South American objects such as basketry, beadwork, ceremonial objects, gourds, preconquest pottery, textiles, and weapons, and more than 160 objects specifically from the Gran Chaco region of Argentina, Bolivia, and Paraguay. ${ }^{23}$

The early modern and colonial periods are generally underrepresented in Canadian collections (Figures 7-9). The Montreal Museum of Fine Arts has a few items from the era, such as silver, ceramics, textiles, and paintings. There is also a small, nearly forgotten collection of early modern Latin American paintings that belonged to Lionel Roy (1905-1967), a former diplomat who worked for two years at the Canadian embassy in Mexico City. ${ }^{24} \mathrm{His}$ collection, exhibited in 1966 at the Musée national des beauxarts du Québec, comprised nineteenth paintings, mostly of different religious topics (see Figure 9). The collection was later purchased by the Musée du Séminaire à Québec (currently Musée de l'Amérique francophone), where it is now preserved. Some of the works were erroneously attributed to European schools but have since been identified as Latin

23. See http://www.mcgill.ca/redpath/collections/ethnology/.

24. Luís de Moura Sobral, email communication with author, May i8, 2017. I also wish to acknowledge the support of Peter Gagné, archivist at the collections branch of the Musée de la Civilisation, who provided me with a listing of this collection. 


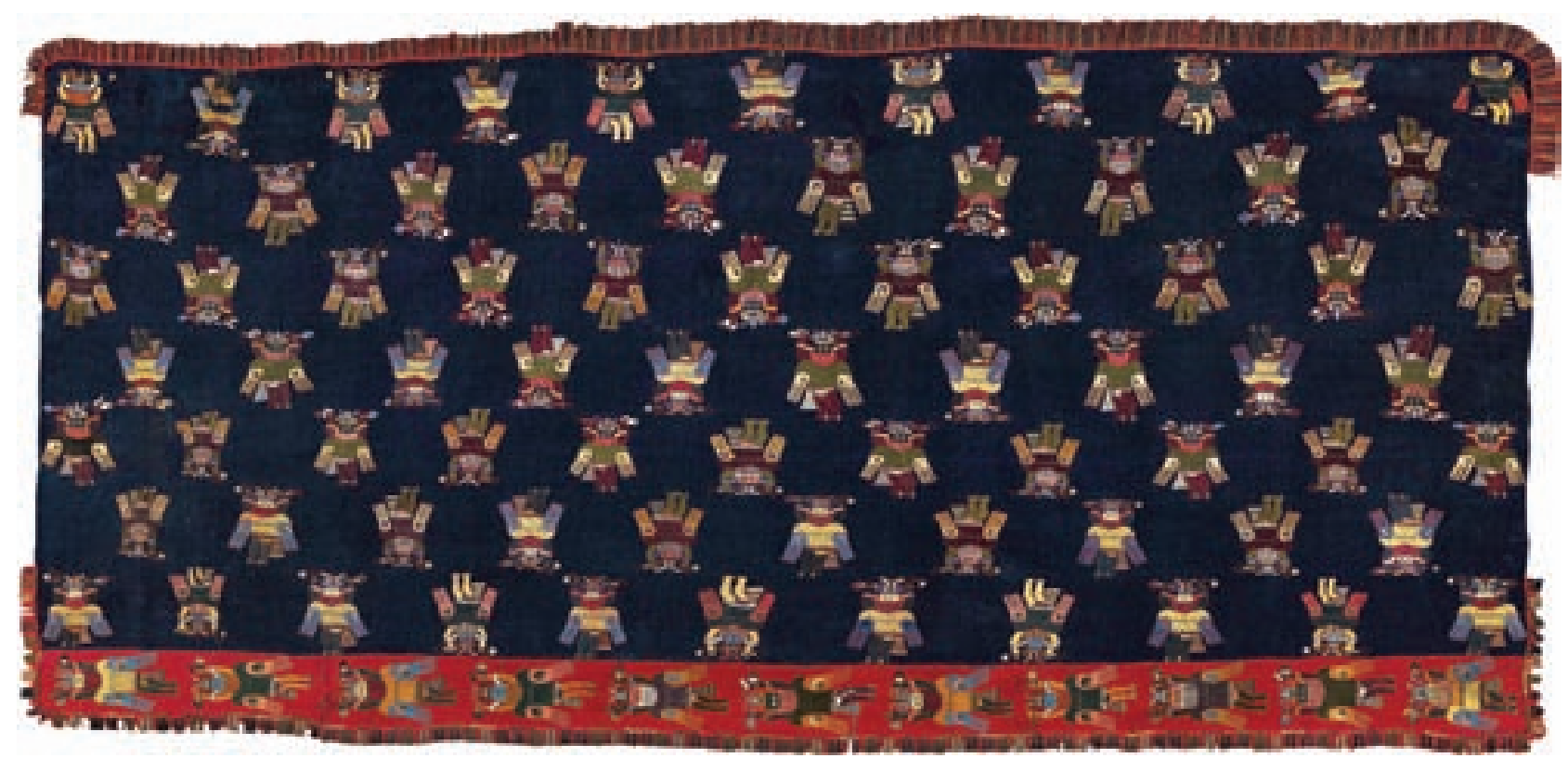

FIGURE 2. Unidentified artist, mantle with anthropomorphic figures, Peru, South Coast, early intermediate period, $200 \mathrm{BCE}-$ $300 \mathrm{CE}$, Paracas Necropolis. Embroidered camelid wool, 46 I $/ 2 \times 98$ in. (II $8 \times 249 \mathrm{~cm}$ ). Montreal Museum of Fine Arts, purchase, gift of F. Cleveland Morgan, 1947.Ad.19. Photo: Denis Farley, courtesy MMFA.

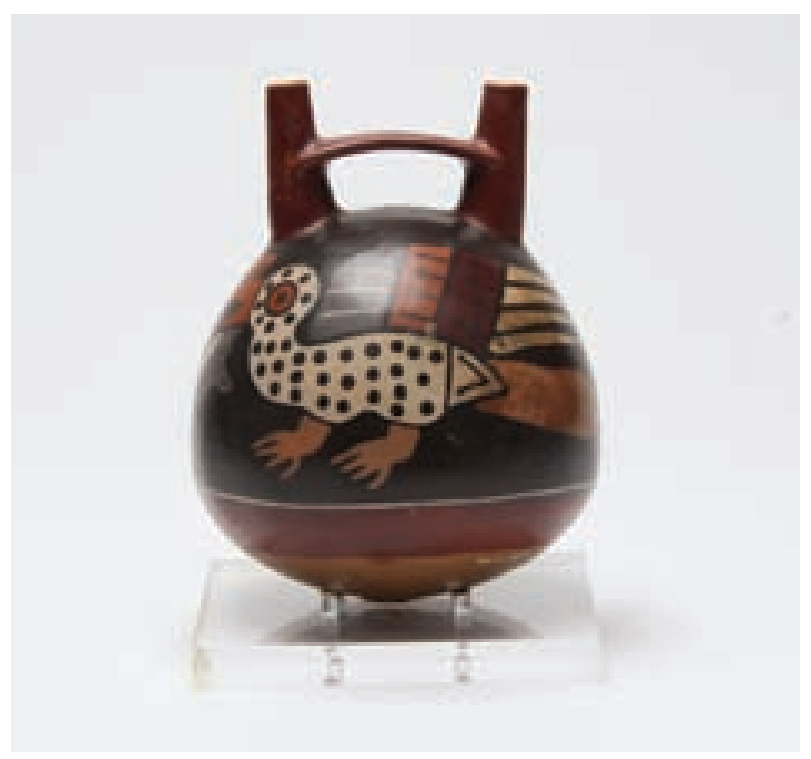

FIGURE 3. Unidentified artist, bridge-spouted bottle with seabirds, Andean area, Peru, South Coast, I00-200 CE. Handbuilt red earthenware, slip, burnishing, 6 I/ $4 \times 5$ in. $(15.9 \times 12.6$ $\mathrm{cm})$. Gardiner Museum, Toronto, gift of George and Helen Gardiner G83.I.I85. Photo: Gardiner Museum.

American colonial works (a phenomenon that also occurs in the United States and many European countries). ${ }^{25}$

25. Luís de Moura Sobral, "Deux tableaux hispano-américains au Musée d'art de Joliette," RACAR 5, no. 2 (1978-79): 99-106; Luís de Moura Sobral,
Proper identification and analysis of the colonial art that does exist in Canadian collections would help solidify its representation and improve the overall visibility of Latin American art.

Modern and contemporary Latin American art enjoys a relatively more robust presence in Canadian collections (Figures IO-I4) despite the general lack of specific expertise in this field among Canadian museums. In terms of attentiveness to contemporary Latin American art, the Montreal Museum of Fine Arts appears to have the most extensive program, followed by the Art Gallery of Ontario, with its interesting focus specifically on Cuban and Brazilian art.

Many Latin American museum collections in Canada were made possible by private collectors with close ties to the institutions. For example, in the case of the Montreal Museum of Fine Arts, collectors' interest in Pre-Columbian art was part of a more general interest in non-Western art, while interest in modern and contemporary Latin

"Un cuadro de Luis Juárez en la Catedral de Quebec," Anales del Instituto de investigaciones estéticas $5 \mathrm{I}$ (1983): 21-23. Luís de Moura Sobral also provided the data referring to a painting of Juan Correa in the Cathedral of Montreal illustrating the Marriage of the Virgin: Elisa Vargas Lugo, José Guadalupe Victoria, et al., Juan Correa, su vida y obra (Mexico City: Instituto de Investigaciones Estéticas / Universidad Nacional Autónoma de México, I985), vol. 2, part I, I2. 


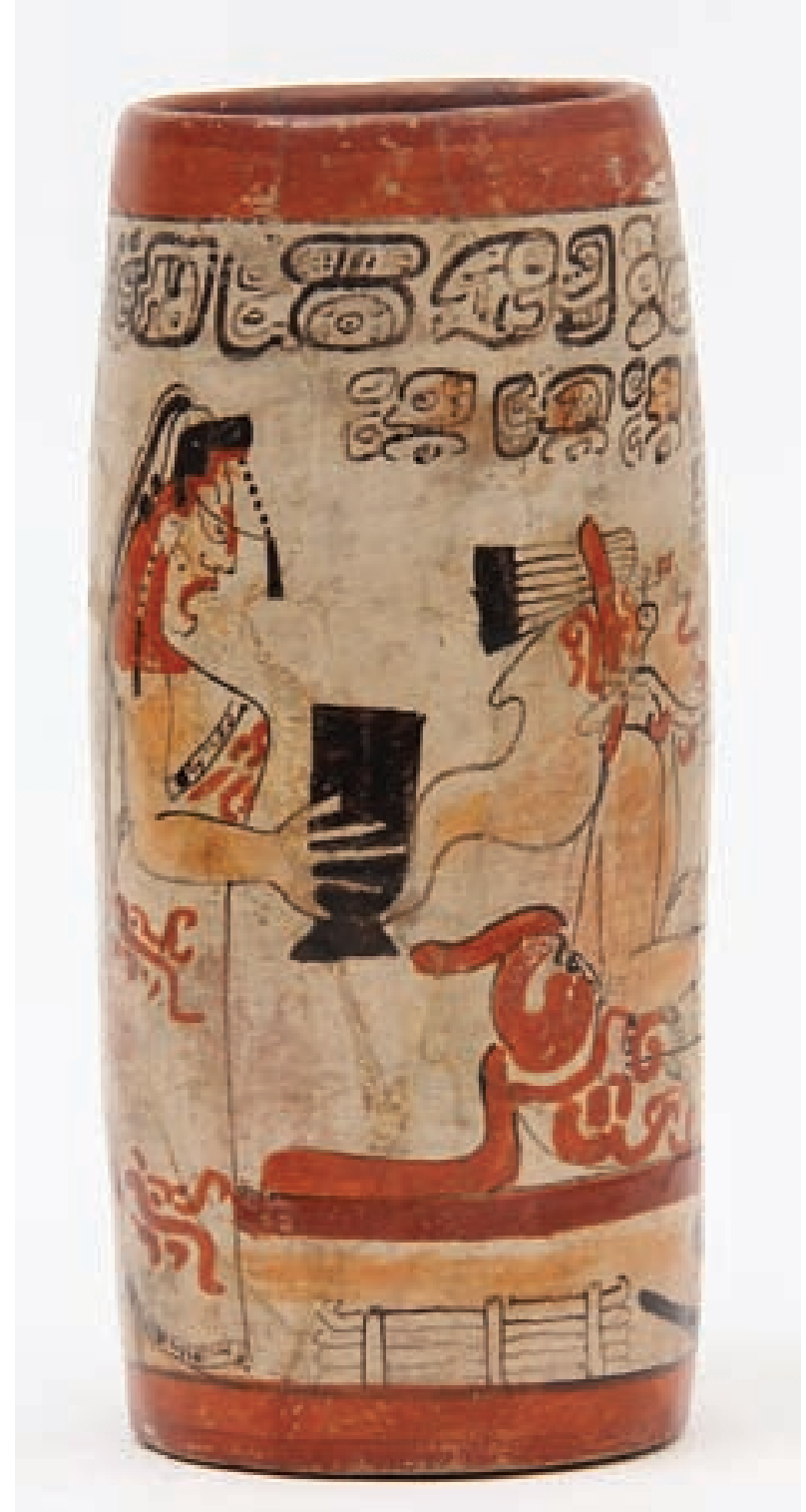

FIGURE 4. Unidentified artist, chocolate-drinking vase with palace scene, Mesoamerica, northeastern Peten (Rio Azul region, Guatemala), 700-800 CE. Hand-built earthenware with slip and red, orange, and black pigment, $83 / 8 \times 3 \mathrm{I} / 2$ in. $(21.4 \times 8.9 \mathrm{~cm})$. Gardiner Museum, Toronto, gift of George and Helen Gardiner, G83.I.I29. Photo: Gardiner Museum.

American art is often linked to the individual collector's personal interest in, and perhaps business connections to, Latin America. ${ }^{26}$ This may be where further inquiries on

26. I am grateful to Erell Hubert, curator of the arts of the Americas at the Montreal Museum of Fine Arts, for sharing this insight.

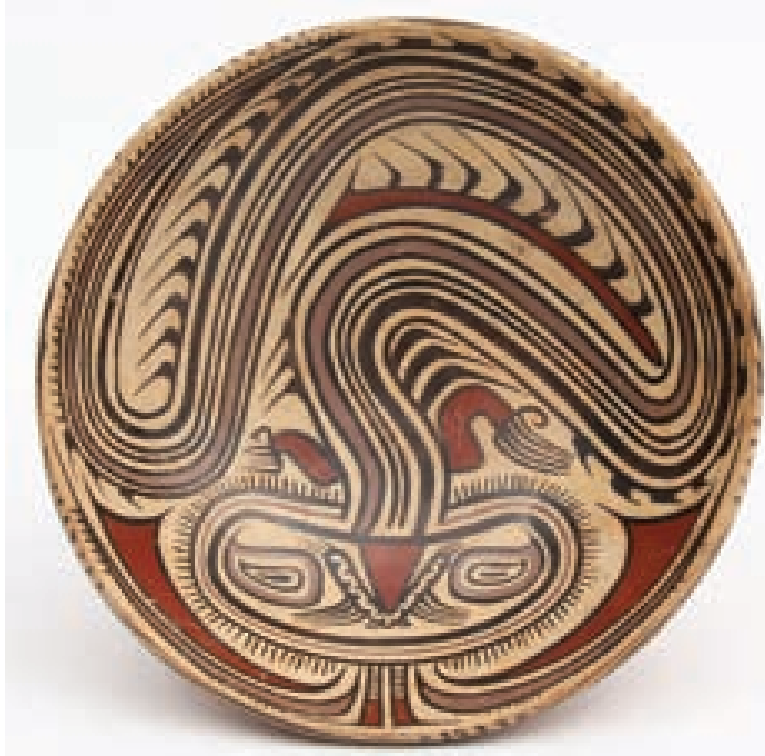

FIGURE 5. Unidentified artist, pedestal dish with serpent design, Intermediate area, Sitio Conte (southern Azuero Peninsula, Panama), 700-900 CE. Red earthenware, white slip, and pigment, $53 / 8 \times$ Io in. $(13.7 \times 25.4 \mathrm{~cm})$. Gardiner Museum, Toronto, gift of George and Helen Gardiner, G83.r.I254. Photo: Gardiner Museum.

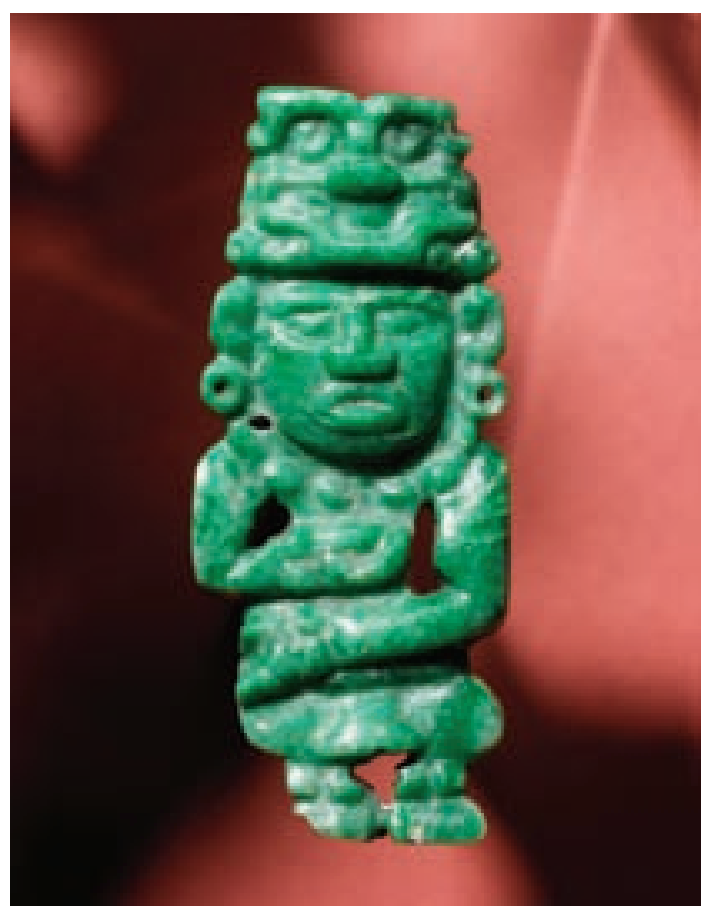

FIGURE 6. Unidentified artist, pendant in the form of a human figure wearing a sun god headdress, Maya, late Classic period, 600-900 CE. Jade, $23 / 4 \times$ I I $/ 8 \times 1 / 2$ in. $(7 \times 3 \times 1.3 \mathrm{~cm})$. Royal Ontario Museum, Toronto, 966.159.43, ROM2004_948_2I. Photo: courtesy Royal Ontario Museum, ( ROM. 


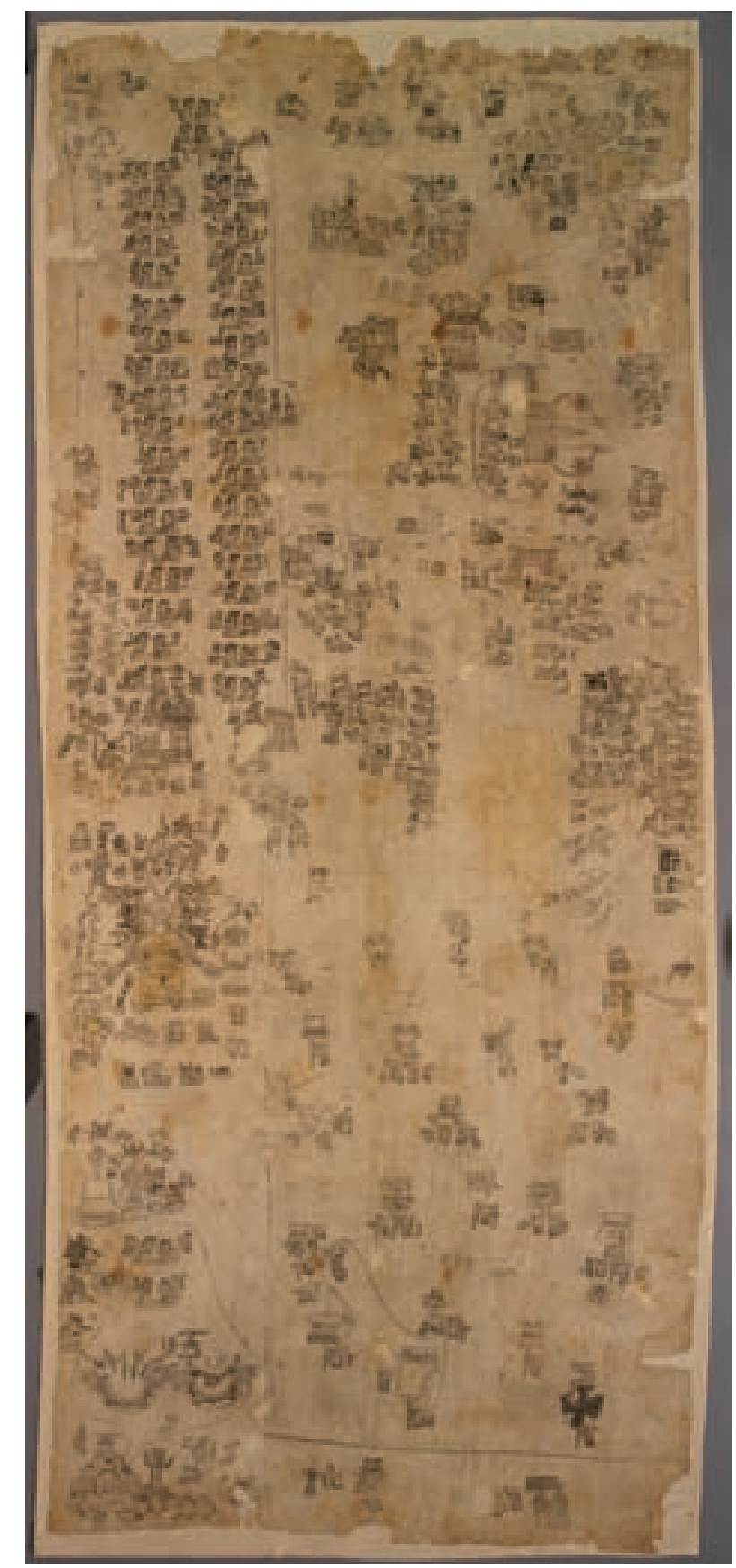

FIGURE 7. Unidentified artist, Lienzo of Tlapiltepec, Mixtec/ Chocho, c. 1575. Woven and polychrome painted cotton, $154 \times$ $66 \mathrm{I} / 2$ in. $(39 \mathrm{I} \times 169 \mathrm{~cm})$. Royal Ontario Museum, Toronto, 917.3, ROM201I_I2080_I. Photo: courtesy Royal Ontario Museum, (c) ROM.

collections of Latin American art in the country should start, because this dynamic may have contributed to the late beginnings of collecting in Canada as well as the uneven efforts toward the works' exposure. Furthermore, the interests of donors do not always align with those of museums,

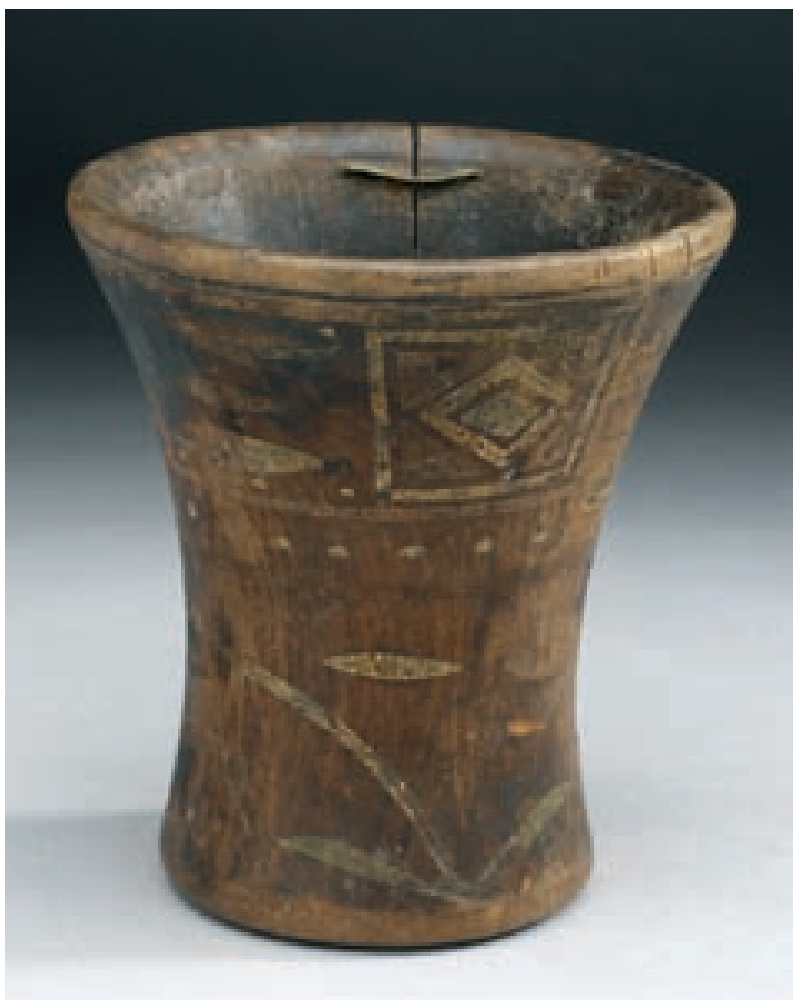

FIGURE 8. Unidentified artist, colonial drinking vessel, Andes, Bolivia, Spanish colonial, $1532-1700$. Wood, 5 I/ $2 \times 5 \times 5$ in. (I4 $\left.\times{ }_{12.5} \times 12.5 \mathrm{~cm}\right)$. Royal Ontario Museum, Toronto, $\mathrm{HP}_{347}$, ROM2007_9019_r. Photo: courtesy Royal Ontario Museum, (c) ROM.

which may explain why Latin American art in Canada is housed in different collections that vary widely in size and content, and as such are given unequal visibility. While some of these collections are part of museums' permanent exhibits, most Latin American art collections remain in storage and are displayed only on special occasions. The generosity of donors has contributed to the building of some wonderful Latin American art collections in Canadian museums, yet there has been no equivalent to, say, the Rockefeller family in the United States. The donations tend to be multiple and modest, and their particular, individual stories have largely remained untold; these should be elaborated and consolidated to offer a more complete vision of the situation. ${ }^{27}$

27. In this sense, a publication such as the one recently edited by Edward J. Sullivan, The Americas Revealed. Collecting Colonial and Modern Latin American Art in the United States (New York: Frick Collection, 2018), but looking at the Canadian collections, is urgently needed. 


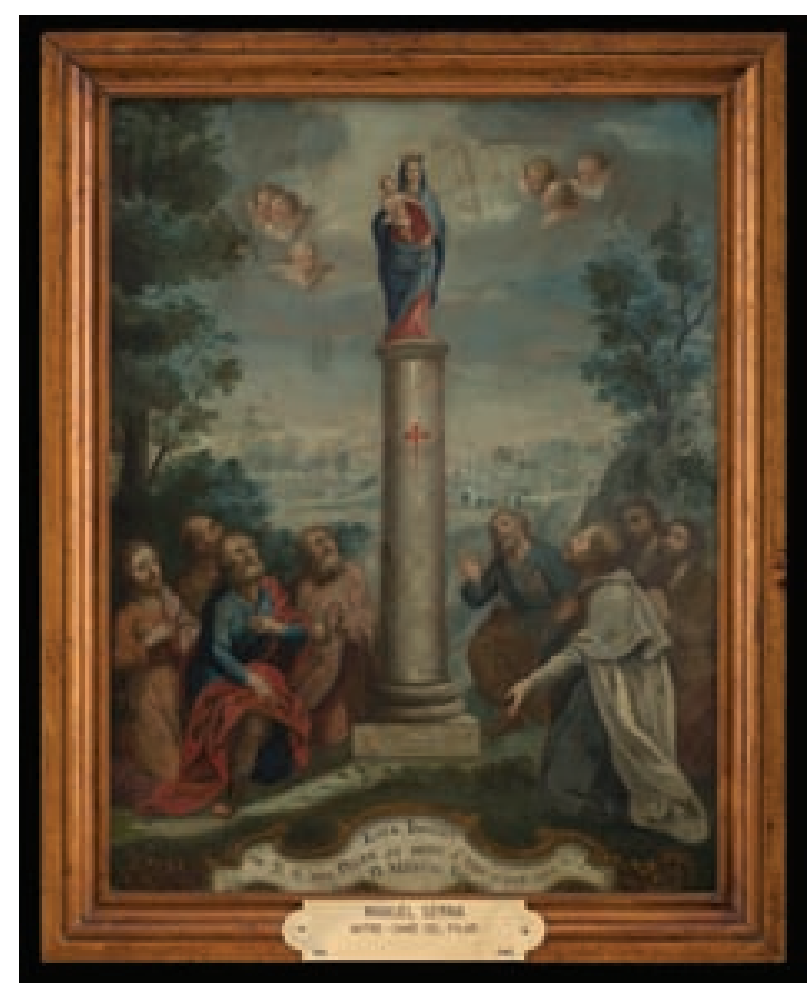

FIGURE 9. Manuel Serna, Our Lady of the Pillar, eighteenth century. Oil on copper, 23 I $/ 8 \times$ I 8 I $/ 2$ in. $(58.7 \times 47 \mathrm{~cm})$. Musée de la civilization, Quebec City, collection du Séminaire de Québec, Icône, I991304. Photo: Red Méthot.

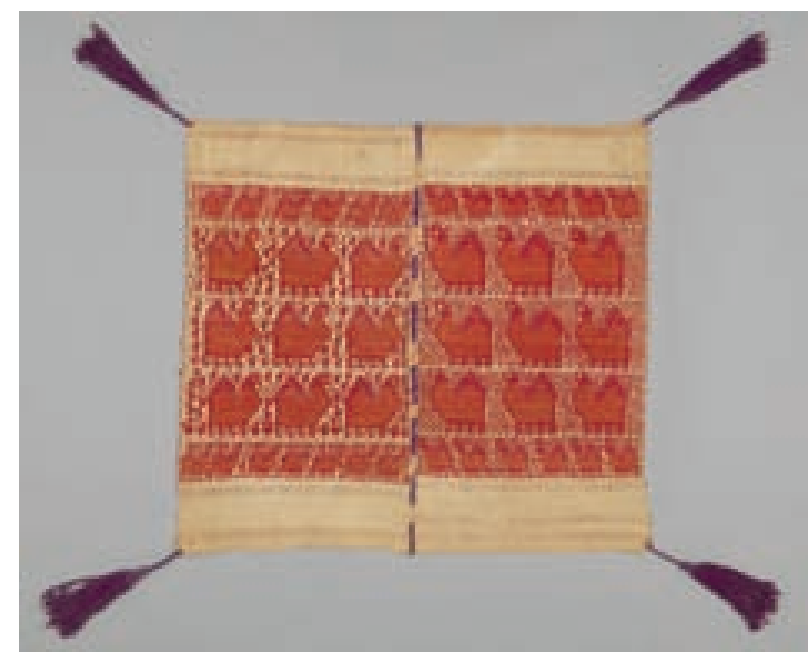

FIGURE 10. Unidentified artist, headcloth (su't), K'iche' Maya, Chichicastenango (Guatemala), c. 1900-1910. Cotton and silk, $223 / 8 \times 25$ I/ 8 in. $(57 \times 64 \mathrm{~cm})$. Textile Museum of Canada, gift of Leslie and Kent Sheppard, T92.0204. Photo: Maciek Linowski, courtesy Textile Museum of Canada.

Starting with the West Coast and moving to the eastern parts of Canada, the following paragraphs consider some

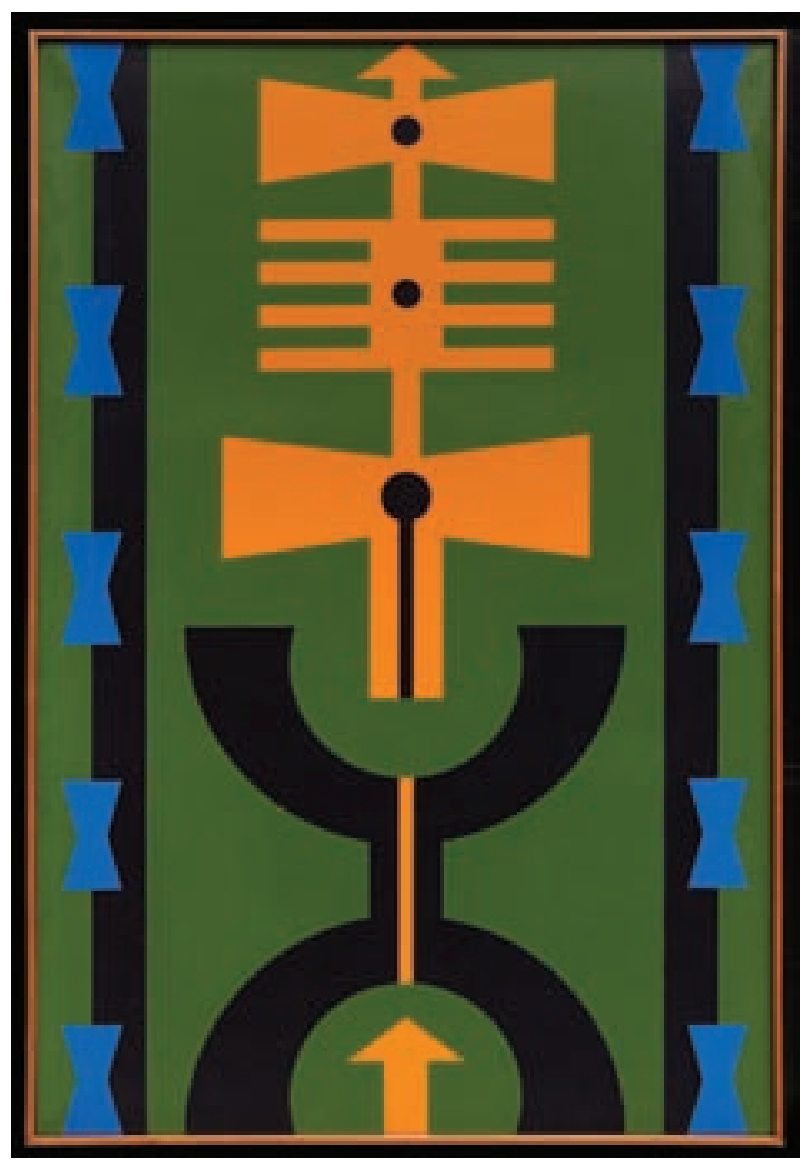

FIGURE 11. Rubem Valentim, Emblem No. 15, 1973. Acrylic on canvas, 59 I/ $4 \times 39$ I $/ 2$ in. $(150.5 \times 100.3 \mathrm{~cm})$. Art Gallery of Ontario, Toronto, gift of Brascan Limited, 1976, 76/189. Photo: (C) Rubem Valentim.

important Canadian collections of Latin American art and visual culture.

The Museum of Anthropology (MOA) at the University of British Columbia has an extensive and wide-ranging Latin American collection. Although the MOA is very clear about its ethnographic (as opposed to art historical) mission, its collection of approximately 4,300 objects from Central and South America contributes to a wide-ranging understanding of Latin American visual culture in Canada. ${ }^{28}$ The objects represent artistic expressions from the Pre-Columbian period (see Figure I) to contemporary ceramics, textiles, silver, musical instruments, secular and

28. MOA's objects come from different regions around the world, and while the best-represented countries are Peru, Mexico, Ecuador, Guatemala, Colombia, Bolivia, Nicaragua, and Brazil, there are also some examples from El Salvador, Panama, Chile, Venezuela, and Argentina. See http://moa.ubc. ca/collections/. 


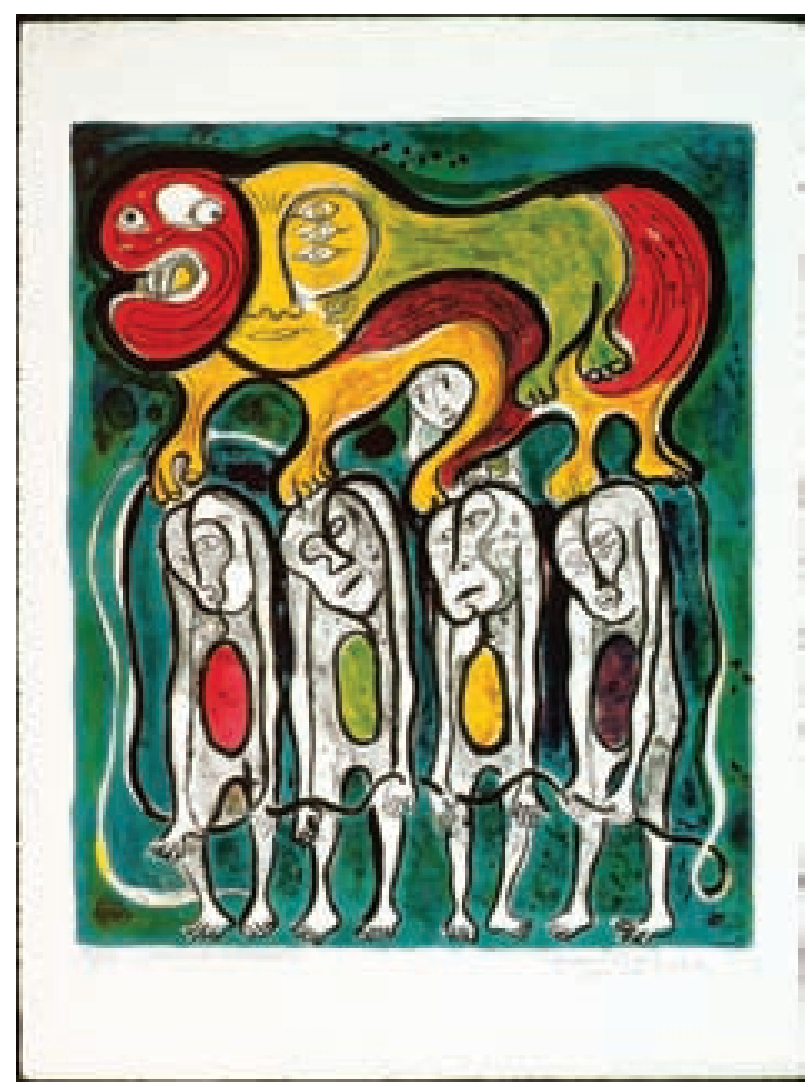

FIGURE 12. Raquel Forner, Mutantes alienados (Mad Mutants), 1974. Lithograph, sheet: $30 \times 22$ I $/ 8$ in. $(76.3 \times 56.3$ $\mathrm{cm})$, image: $23 \mathrm{I} / 2 \times 19 \mathrm{I} / 4 \mathrm{in} .(59.7 \times 49 \mathrm{~cm})$. Montreal Museum of Fine Arts, gift of Guillermo de Andrea, 2000.142. Photo: Christine Guest, courtesy MMFA.

religious sculptures, paintings (see Figure I4), masks, toys, jewelry, baskets, handicrafts, and beyond. The collection has been assembled by academics and specialists closely connected with the university. ${ }^{29}$ The museum claims that its gallery "of Central and South American, Caribbean and Iberian art and artifacts is the only permanent one in Canada dedicated to this part of the world. ${ }^{30}$ The museum is also very active in curating special exhibitions (see appendix I for a full list of special exhibitions of Latin American art in Canadian museums).

29. Mexican masks and mid-twentieth-century Andean folk art donated by UBC professors Alfred Siemens and Blanca and Roberto Muratorio; Guatemalan costumes collected by Elizabeth Johnson; Quechua clothing and Andean and Pre-Columbian textiles collected by Mary Frame; and American Southwest ceramics contributed by Marianne Dozier. Anthony Shelton, "The Central and South American Collections," in The Museum of Anthropology at the University of British Columbia, ed. Carol E. Mayer, Anthony Shelton, and Pam Brown (Vancouver: Douglas and McIntyre, 2009), 84.

30. Shelton, "The Central and South American Collections," 84.

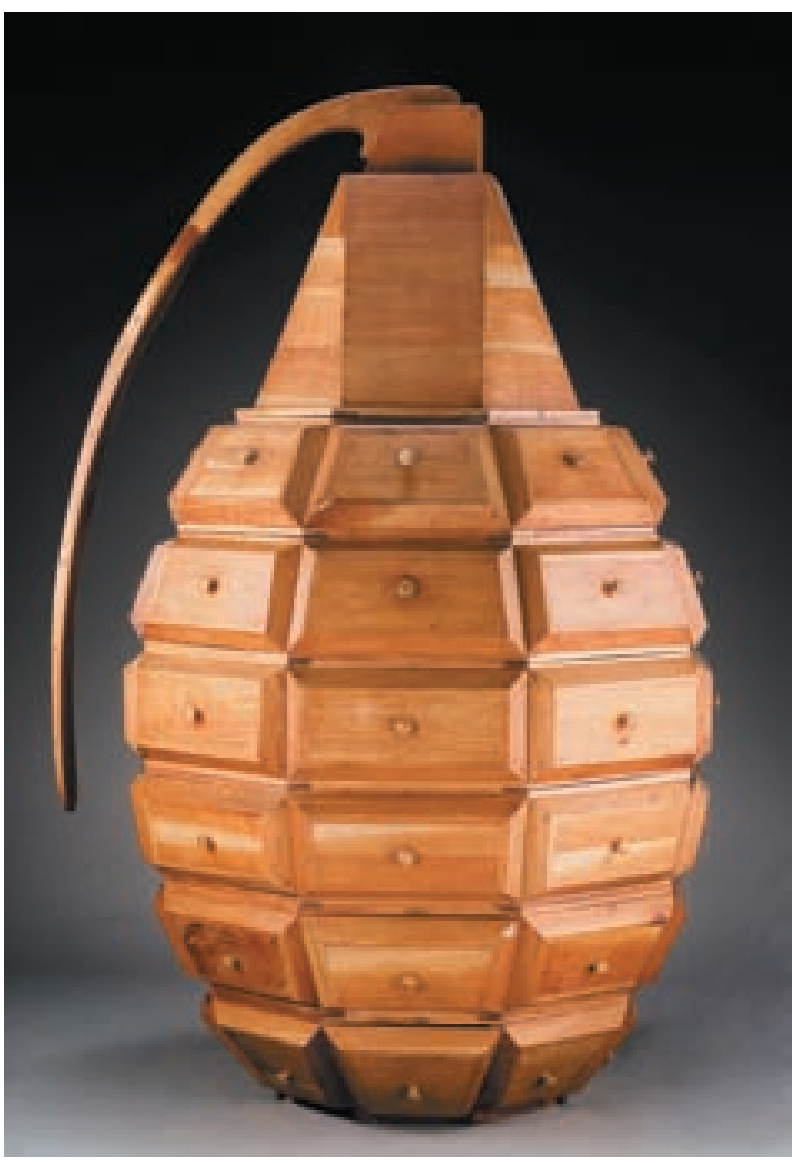

FIGURE 13. Los Carpinteros, Estuche (jewelry case), I999. Cypress wood, $885 / 8 \times 51$ I $/ 8 \times 51$ I $/ 8$ in. $(225.1 \times 129.9 \times 129.9$ $\mathrm{cm})$. Montreal Museum of Fine Arts, purchase, the Museum Campaign 1988-1993 Fund, 2008.62.I-32. Photo: Christine Guest, courtesy MMFA.

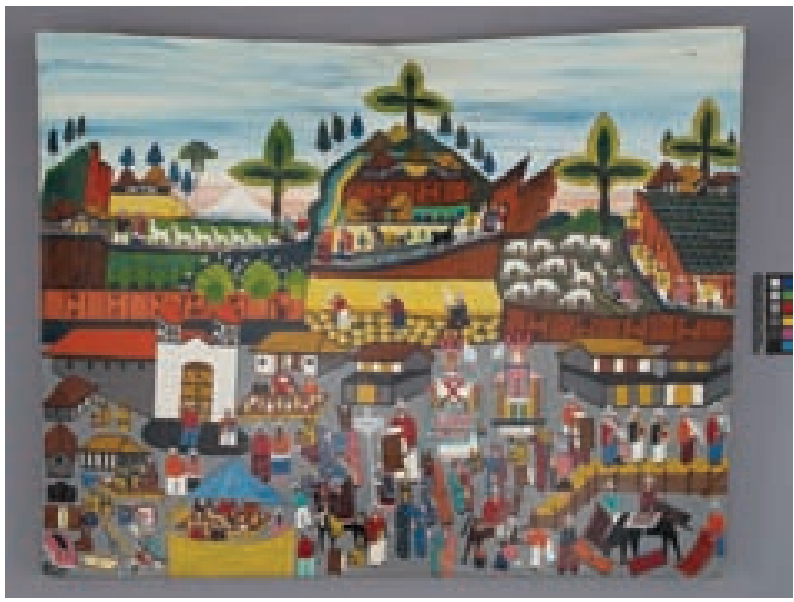

FIGURE 14. Unidentified artist, Tigua painting, Cotopaxi (Tigua, Ecuador), date unknown. Oil on animal skin, $213 / 4 \times 27 \mathrm{I} / 2 \times$ I I $/ 8$ in. $(55.3 \times 70 \times 3 \mathrm{~cm})$. Museum of Anthropology, Vancouver, donated by Blanca and Ricardo Muratorio, 2903/53. Photo: Kyla Bailey, courtesy UBC Museum of Anthropology, Vancouver. 
Meanwhile, in Toronto, the contemporary Latin American collection of the Art Gallery of Ontario (AGO) comprises forty-five artworks by artists of different nationalities. ${ }^{31}$ Among the gallery's notable pieces is its first purchase back in 1968, a piece by the Venezuelan kinetic artist Jesús Rafael Soto. Brascan Limited, a natural resources company with holdings in Canada and Brazil, enriched the AGO Latin American collection in 1976 with its important contribution of seventeen Brazilian artworks, including sculptures by Yukata Toyota, assemblages by Osmar Dillon, and paintings by Tomie Ohtake, Arcangelo Ianelli, and Rubem Valentim (see Figure ir). The company's donation amounted to half of the works shown in the exhibition Io Brazilian Artists/ro artistes brésiliens, which was organized by and presented at the AGO in April 1975 and then circulated throughout Canada. ${ }^{32}$ In the late I990s, a volunteer committee contributed acquisition funds that led to the purchase of works by Doris Salcedo (Colombia), Guillermo Kuitca (Argentina), and Eugenio Dittborn (Chile). Then in 2004, Ron Benner, an artist based in London, Ontario, donated four drawings by Cuban artist José Bedia. Rounding out this diverse collection is Sherritt International corporation's important 2017 donation of Cuban art totaling eight pieces, including installations by Wilfredo Prieto, Los Carpinteros, Reynier Leyva Novo, Carlos Garaicoa, Rodolfo Peraza, and Lázaro Saavedra. The most recent acquisition was an anonymous gift of an installation by the Cuban artist Tania Bruguera. The AGO's collection of Cuban art, currently the largest in Canada, was exhibited for the first time in As If Sand Were Stone: Contemporary Latin American Art from the AGO Collection in summer 2017.33

The AGO also holds photographs by Gabriel Orozco, Tina Modotti, Manuel Álvarez Bravo, and Lola Álvarez Bravo. The impressive Lola Álvarez Bravo collection, which mostly illustrates archaeological sites, artifacts, and ruins, was an anonymous gift; meanwhile, the Modotti and Manuel Álvarez Bravo photographs were partly donated and partly purchased, and exhibited in 2014 to mark the AGO's acquisition of the Harry and Ann Malcolmson

31. I wish to thank Adelina Vlas, associate curator of contemporary art at the AGO, Sophie Hackett, curator of the photography collection, and her assistant Jill Offenbeck for the information they shared with me.

32. [No author], Io Brazilian Artists / Io artistes brésiliens (Toronto: Art Gallery of Ontario, 1975). Regarding Brascan see Patricia Best and Ann Shortell, The Brascan Ring: Power, Influence and the Brascan Empire (Toronto: Ballantine, 1990).

33. See http://www.ago.net/latinamerica.
Collection. ${ }^{34}$ Finally, a group of thirty-four photographs of the 1973 Ezeiza massacre in Argentina complements the Latin American photography collection. Again, in this case, there is not a clear collecting strategy: the items were partly donated and partly purchased, depending on opportunities.

The leading ceramic museum in Canada, Toronto's Gardiner Museum, has an important collection of PreColumbian earthenware. The ancient Americas collection is divided into the American Southwest, Andean, Intermediate Area, and Mesoamerica subsections, encompassing many separate cultures that date back as far as 3500 BCE until shortly after the arrival of the Spanish in 1550 CE. ${ }^{35}$ The collection's few US Southwest examples correspond to the Aridoamerican culture, living in what is now Colorado, New Mexico, Arizona, and Utah. Of the four subsections, the Mesoamerican collection is by far the most extensive, comprising numerous objects from the modern countries of Mexico, Guatemala (see Figure 4), El Salvador, Honduras, and Belize. The Andean region is represented with several artifacts, mostly from the Pacific coastal areas or highland regions of what are now Bolivia, Chile, Colombia, Ecuador, and Peru (see Figure 3). Finally, the Intermediate Area includes a few necklaces, pendants, vessels, figures, dishes, and jars from the modern countries of Nicaragua, Costa Rica, and Panama (Figure 5). While the American Southwest artifacts were gifted by the Rath family to the Gardiner Museum, the Andean, Intermediate Area, and Mesoamerican ceramics were part of the original donation given by George and Helen Gardiner in 1984 .

The Royal Ontario Museum (ROM) has in its holdings numerous Latin American artifacts divided across different but intersecting ethnographic, archaeological, and textile collections. ${ }^{36}$ In addition to actively exhibiting these in Latin American displays, the ROM also publishes catalogues and specific studies of their collections in recognition of the fundamental value of its Latin American collection to the Canadian context. Acknowledging the educational merits of this collection through its displays ensures "that Canadians with Latino backgrounds find connections to their heritage within the Canadian

34. See http://www.ago.net/malcolmson-collection-exhibition.

35. See https://www.gardinermuseum.on.ca/collection_type/ ancient-americas/.

36. I am grateful to Justin Jennings, curator of New World archaeology, and Nicola Woods, rights and reproductions coordinator, at the ROM for their guidance via email communications, August and September 2017. 
patrimony.... Since that part of the population is significantly on the rise, this display now reflects an important facet of Toronto's cultural landscape." ${ }^{37}$

Among the artifacts that have brought much attention to the collection is the Lienzo of Tlapiltepec (see Figure 7), a Mixtec-Chocho manuscript painted on cotton cloth, alongside the more than one thousand Zapotec and Mixtec urns known as the Rickards Collection, of which many have proved to be modern forgeries. ${ }^{38}$ The ROM acquired the Rickards collection in 1919 from Constantine Jorge Rickards (1876-1950), a wealthy Englishman who grew up in Oaxaca and later lived in Mexico City.

Furthermore, the Latin American ethnographic collection offers a variety of objects from different cultural groups, historical moments, and geographical areas such as Mexico, Central America, the Caribbean, and South America (see Figure 8). The collection, which was built from the beginning of the twentieth century until the 1960s, has more than 3,500 artifacts, of which around one thousand are textiles. ${ }^{39}$ While the ROM moved very slowly in expanding its ethnographic collections from Latin America, it has continued to grow mainly through fieldwork and donations, especially since the hiring of Latin American specialist Helmuth Fuchs as the first curator of this collection.

Meanwhile, the ROM has shown an interest in expanding upon its 1950s-era archaeological explorations in Latin America. ${ }^{40}$ It has broadened its archaeological section acquisitions through donations, excavations, and museum purchases, of which the most important are from Belize (see Figure 6). ${ }^{41}$ There is also a smaller presence of artifacts from the Mesoamerican areas of Mexico, Honduras, and Guatemala in the ROM's archaeological collections. These artifacts include textiles, stone and ceramic objects, glass beads, metal pots, worked animal bone, and pearls, among other things. The museum also has an Andean collection that came from Peru, Ecuador, and Bolivia, as well as a small

37. Arni Brownstone, "Ethnology: Latin America," internal document, ROM, Toronto, October Io, 2012.

38. Arni Brownstone et al., The Lienzo of Tlapiltepec: A Painted History from the Northern Mixteca (Toronto: ROM, 2015); Adam T. Sellen, "Authenticity Testing in Canadian Museums," Voices of Mexico 48 (1999): 69-72; Adam T. Sellen, "Breve historia sobre la colección Rickards en el Museo Real de Ontario," Estudios Mesoamericanos I (2000): 14-23; Adam T. Sellen, "The Face That Launched a Thousand Fakes," Archaeological Newsletter 3, no. 13 (2002): 32-39.

39. Brownstone, "Ethnology: Latin America."

40. Justin Jennings et al., Maya: Secrets of the Ancient World (Toronto: ROM, 2011), 63-69.

4I. Justin Jennings, email communication with author, August IO, 2017.
South American collection from Brazil and British Guyana. While Kent Day was previously the only ROM archaeologist who had worked in South America, the museum hired Justin Jennings in 2006 as a specialist on southern Peru. The ROM has contributed significant knowledge of different archaeological sites in Latin America through its excavations, yet because of laws restricting the export of archaeological artifacts, the fieldwork has not contributed materially to the ROM's collections.

Finally, the departments of Textiles and Ethnology at the ROM have jointly acquired several substantial Latin American textile collections since the I970s, with particularly strong examples of hand-loomed textiles and costumes. The collection of regional textiles and costumes includes more than 350 pieces from Pre-Columbian Peru, while textiles from Mexico, Central America (mostly Guatemala), and the Caribbean, spanning from the eighteenth century to the present day and acquired through donations and fieldwork, form part of the Ethnology collection. ${ }^{42}$ The first two donations of Mexican textiles to the ROM came in 1943, via longtime supporters with interesting connections to Mexico. Murray and Marguerite Vaughan owned a house in Cuernavaca from 1954 until the I980s and donated finely embroidered textiles to the ROM; they were friends with Doris Heyden, a leading American scholar of Mexican culture who lived in Mexico City. ${ }^{43}$ The Newcomb/Beck donation of 116 pieces to the ROM in the late 1970s was originally collected by Eman Lycurgus Beck, Kent Newcomb's grandfather, who lived in Mexico City from the r 860 os until his death. Beck would sometimes trade parts of his collection with his friends, such as Franz Mayer, a financier of German origin who spent most of his life in Mexico and was likewise an avid collector. ${ }^{44}$ The ROM's textile purchasing strategies have been actively informed by the research expertise of the curators as well as by direct contact with specialists and supporters in this area. More recent acquisitions that reflect these networks

42. See Chloë Sayer, "Collecting Mexican Textiles and Costumes at the Royal Ontario Museum," in Mexico: Clothing and Culture (Toronto: ROM, 2015): 123-39.

43. Sayer, "Collecting Mexican Textiles and Costumes at the Royal Ontario Museum," 128-29.

44. Sayer, "Collecting Mexican Textiles and Costumes at the Royal Ontario Museum," I29-31. On Franz Mayer, his collection, and his museum see Héctor Rivero Borrell M. et al., The Grandeur of Viceregal Mexico: Treasures form the Museo Franz Mayer / La grandeza del México virreinal: tesoros del Museo Franz Mayer (Houston: Museum of Fine Arts; Mexico City: Museo Franz Mayer, 2002) and http://www.franzmayer.org.mx. 
were made in 2014 through an endowment fund that has enabled ROM specialists to document changes in dyes, patterns, and scales. ${ }^{45}$

Another key institution is the Textile Museum of Canada, also located in Toronto, with its impressive collection totaling 1,717 objects that represent different eras and countries of Latin America. ${ }^{46}$ From Central America there are textiles from Guatemala, Belize, and the San Blas Islands. The Guatemalan collection consists of mostly women's blouses (buipiles), along with skirts, bags, hats, hair ties (see Figure Io), shawls, and belts; there are also men's trousers, shirts, jackets, belts, and head cloths. The majority of the collection, which represents a large number of communities from throughout the country, dates from the mid-twentieth century to the present, with a few rare older examples. This collection was expanded in 1994 through a large donation of Latin American textiles as part of a major gift called the Opekar/Webster Collection that included textiles from many areas of the world. Finally, the museum acquired Guatemalan textiles in 2013 from donor Donna Stewart, a doctor who became acquainted with some of the local weavers during her regular medical work trips to a number of Guatemalan villages. ${ }^{47}$ The geographical and historical dimensions of the Stewart collection artifacts greatly increase the breadth and depth of the museum's current holdings, and extend the representation of Guatemalan textiles well up to the present.

The museum's Mexican textile holdings include several serapes from the eighteenth and nineteenth centuries as well as an assortment of women's blouses, shawls, skirts, and belts, and men's ponchos, shirts, trousers, belts, bags, hats, and samplers. There are also examples from other areas in Mexico such as the Maya communities in Chiapas, the Huichol, the Mixtec, and the Nahua peoples. The museum's textile holdings from South America come from

45. Sayer, "Collecting Mexican Textiles and Costumes at the Royal Ontario Museum," 138.

46. I want to acknowledge support received from Roxane Shaughnessy, curator of the Latin American collection at the Textile Museum of Canada in email communications, May-August 2017. Shaughnessy spent many years researching and developing this section of the collection in partnership with the museum's donors, while also actively working to rehouse the museum's storage of its ancient Peruvian textiles through initiatives that would ensure their care and preservation while encouraging scholarly access and public interest. The collection can be searched online: http://collections.textilemuseum.ca.

47. During these visits, Dr. Stewart collected exceptional examples of local weaving that trace the evolution in artistry and design of Maya dress from the twentieth century into the twenty-first.
Peru, Bolivia, Ecuador, Chile, Brazil, Paraguay, Guyana, Venezuela, and Uruguay, including a strong collection of Bolivian alpaca fiber weavings from the late nineteenth through the mid-twentieth centuries as well as numerous Pre-Columbian textiles from Peru that date as far back as I00 to $1500 \mathrm{CE}$, which exist alongside weavings and some knitted textiles from the more recent past. Some of the latest acquisitions include a collection of molas (blouses) from Panama from the twentieth and twenty-first centuries. In 2002 the museum collected Peruvian textiles from villages in the Cuzco area, including weavings from the mid- to late twentieth century such as shawls, skirts, belts, hats, ponchos, knitted items, weaving tools, and yarn. Most of these contemporary weavings are from villages that work with the Centre for Traditional Textiles in Cuzco to support weavers in the revival and marketing of their traditional weaving techniques, practices, and products. ${ }^{48}$ There is also a collection of $i k a t$ woven ponchos and shawls from Ecuador from the early to mid-twentieth century, two rare Mapuche chief's ponchos from Chile (Figure 15), and cloths made by the Shipibo people from the Amazon area. The museum has been dynamically engaging with the Latin American communities in Toronto in their public and education programs over the years. It also actively publishes catalogues and organizes special exhibitions.

In Quebec, the Montreal Museum of Fine Arts has the most impressive Latin American collection, with around 1,250 Pre-Columbian objects (see Figure 2) and more than 250 items from the colonial era up to today (see Figures I2, 13)..$^{49}$ The countries of origin of these artifacts vary widely, but include Mexico, Peru (see Figure 2), Guatemala, Brazil, Cuba (see Figure 13), Panama, Chile, Argentina (see Figure 12), Colombia, and Ecuador. At this museum, modern and contemporary art are well represented in the work of famous artists operating across a range of mediums. These include Raúl Anguiano, Eduardo Basualdo, Félix Beltrán, Pedro Coronel, Miguel Covarrubias, Carlos Cruz-Diez, José Luis Cuevas, Raquel Forner (see Figure I2), Wifredo Lam, Gerardo Murillo (also known as Dr. Atl), José Clemente Orozco, Diego Rivera, David Álfaro Siqueiros, and Rufino Tamayo. In recent years there have been greater efforts at acknowledging the

48. "By Weavers, for Weavers," Centro de Textiles Tradicionales del Cusco, http://www.textilescusco.org/.

49. I want to thank Erell Hubert for providing me with an exhaustive list of exhibitions held at the Montreal Museum of Fine Arts, as well as a list of the Latin American collection. 


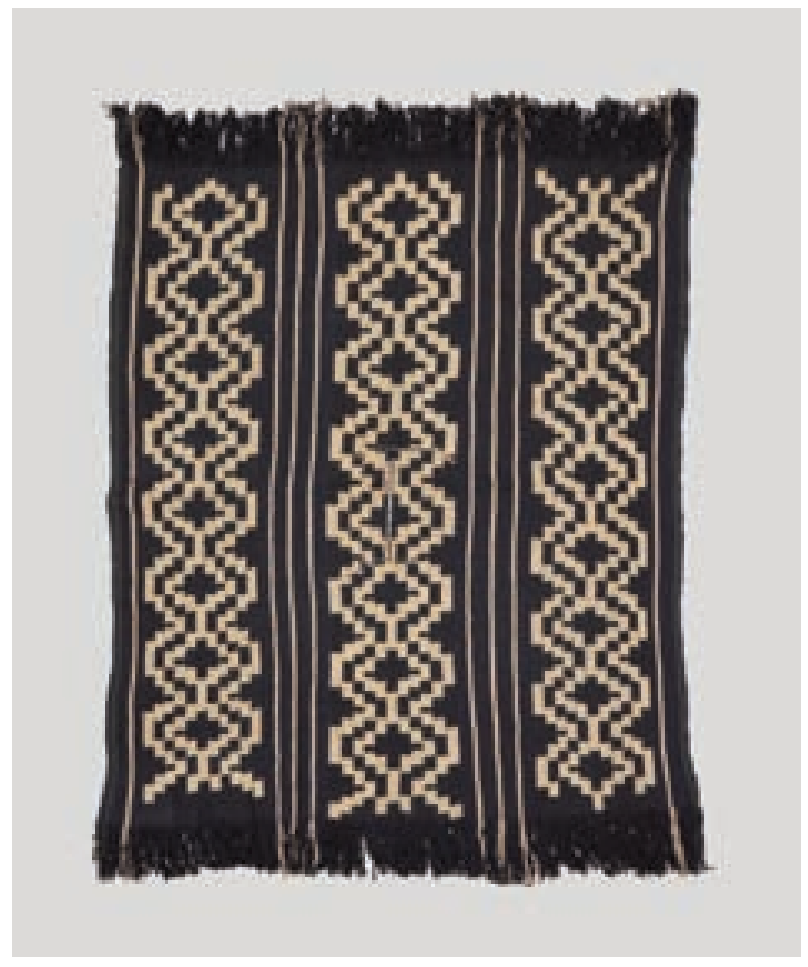

FIGURE 15. Unidentified artist, trarikanmakuñ (poncho), Mapuche, Chile, late nineteenth century. Wool, $597 / 8 \times 52$ in. $(152 \times 132 \mathrm{~cm})$. Textile Museum of Canada, gift of Dr. Daniel and Mrs. Sharon Pollock, T91.0358. Photo: Maciek Linowski, courtesy Textile Museum of Canada.

presence of this collection in the museum. For example, a Latin American art gallery was inaugurated in 2008 , followed by the appointment in 2009 of the collection's first curator of Pre-Columbian art. Vital donations were offered to the museum between 2006 and 20II, continuing a history of collecting Pre-Columbian art that started as early as 1916. ${ }^{50}$ On top of exhibiting Latin American art and publishing catalogues, the museum is currently restructuring the collection in new and larger galleries with the intention of opening a dialogue between Pre-Columbian and more modern works.

The listing provided here is only a sample of the abundance and richness of Latin American art and visual culture in Canadian public collections. It is a way to engage audiences into learning more about this vast heritage. Another way for Canadian museums to participate into Latin American art has been through temporary exhibitions.

50. For a detailed history of the constitution and consolidation of the collection of Pre-Columbian art see Erell Hubert and Victor Pimentel, "Les arts précolombiens au Musée des beaux-arts de Montréal," RACAR 38, no. 2 (2013): 7-2I
EXHIBITING LATIN AMERICAN ART IN CANADA

The relative success of numerous Canadian exhibitions of Latin American art, despite difficulties in aligning the interests of stakeholders such as the government, private industry, museum board members, donors, and private collectors, seriously challenges the assumption that Canadian museums and galleries do not actively support Latin American art. On the contrary, their devotion of resources toward generating scholarship that often preceded or exceeds the work of any university department in the field of art history must be recognized and celebrated.

Appendix r compiles a list of special exhibitions on Latin American art held in different cultural institutions in Canada, and attests to the complexity of the exhibitions and their histories. The web pages of approximately seventy Canadian museums were reviewed, and more than one hundred temporary exhibitions of Latin American art identified. ${ }^{51}$ The exhibitions were mainly in urban areas of British Columbia, Ontario, and Quebec, in cities such as Vancouver, Victoria, Ottawa, Toronto, Montreal, and Quebec City, all vibrant artistic centers. The exhibitions listed not only cover a wide variety of time periods and geographies, but also address specific topics and issues faced by artists and curators.

Specialized curators at Canadian museums are also an important part of the equation, although I did not pursue concrete data from them for this paper. This is an avenue for further consideration. Curatorial residencies should also be explored further, as should reciprocal art exhibitions from Canada traveling to Latin America. ${ }^{52}$ At this point I am not making a distinction between exhibitions curated by Canadian museums versus exhibitions planned by other institutions that traveled to Canada as part of "global artistic circuits," but touring exhibitions are also a topic that would require more exploration. ${ }^{53}$ Eventually it could be interesting to see to what extent the institutions rely on their permanent collections versus local networks

51. This list is by no means exhaustive. The main limitation is that I depended on the information available online, which varies widely from one museum to another. Information on past exhibitions is sometimes incomplete, especially the further back you wish to look. I might have missed exhibitions if the titles did not disclose their Latin American content.

52. See for example Kirsty Robertson, Stephanie G. Anderson, Elizabeth Diggon, Ahlia Moussa, and Sarah E. K. Smith, "More a Diplomatic Than an Esthetic Event: Canada, Brazil, and Cultural Brokering in the São Paulo Biennial and 'Isumavut," Journal of Canadian Studies 47, no. 2 (2013): 60-88.

53. I borrow this expression from Héctor Olea, Mari Carmen Ramírez, and Tomás Ybarra-Frausto, "Resisting Categories" in Resisting Categories, 40. 
of private collectors when the exhibitions are developed in-house. Nor did I take into account the institutions sponsoring the exhibitions. In most cases, this information was not provided on the web pages of the museums. Although I recognize the value of this information, at the moment I am mostly interested in determining where and when people could be exposed to Latin American art in Canada outside academia, although some universities' museums and galleries were considered. There are diverse interests at stake behind art exhibitions, and studying them in detail in relation to Latin American art in Canada would be beyond the scope of this essay.

The information in appendix $\mathrm{I}$ is organized from west to east, and then in alphabetical order by museum name. The exhibitions are listed in chronological order, starting with the most recent. In some cases, a single exhibition traveled to different locations in Canada, so it is mentioned more than once. When possible I list the catalogues that accompanied the exhibitions as tangible material available for consultation. The specific histories, contexts, contents, and receptions of these shows are pending.

Scholarship has recognized different waves of Latin American art exhibitions in US museums, illustrating "the cyclical nature of the American fascination with Latin America." ${ }^{54}$ In the 1940s major exhibitions organized by US museums focused on Mexican artists and culture as a way to reinforce hemispheric unity and antagonize the expanding influence of fascism in Europe. These exhibitions provided important public exposure since they were large and traveled to multiple venues. In the early 1960 another wave of interest in Latin American art exhibitions came forth, answering Washington's concern with the Communist movements, due mainly to escalation of the Cold War and the upsurge created by the Cuban Revolution. During that time the degree of US investment in Latin American countries grew drastically, and many cultural projects benefited: an increasing number of Latin American art exhibitions took place in the United States, and important collections were initiated. In the mid-I980s a third wave of exhibitions occurred at different museums and galleries across the United States due to the reestablishment of democracies in many countries of Latin America, the coming to power of neoliberal governments, and early negotiation of the North American Free Trade Agreement (NAFTA).

54. Cancel, "Introduction," 9. For this section I am also in debt to Ramírez, "Brokering Identities," 19-22.
Financial interests from Latin America largely promoted this third wave, which brought "fluid transit of artists, exhibitions, curators, private sponsorship, and a novel breed of entrepreneurial collectors who circulate between the international art centers and the Latin American capitals." ${ }^{\prime 5}$ At the turn of the millennium the role of the curator underwent a major shift, from one of exclusive arbiter of tastes and quality to something closer to mediator of cultural exchange, or "cultural broker."

Do the same political and diplomatic interests apply in Canada as in the United States? Is the field of Latin American art and its exhibitions conceptualized in Canada in similar or different ways than in the United States? What have been the messages transmitted in Canadian exhibitions of Latin American art? How do museums and the art establishment in general respond to the cultural demands of an increasing Latin American community in Canada? More reflection is needed to answer those questions, but some initial ideas can be drawn from the appendix. In general, US and Canadian politics tend to be aligned. There seem, however, to be fewer exhibitions in Canadian museums that encompass wide swaths of time and space under the rubric "Latin America," and more shows about particular artists, national movements, or traditions. This is interesting considering that comparatively in the I990s in the United States there was a wave of "Latin American" exhibitions that came under attack as encompassing overly diverse contexts and currents.

The attached appendix confirms that Canadian cultural institutions have long been interested in exhibiting art from this region of the world. From the information gathered so far, the earliest exhibition of Latin American art in Canada, titled Contemporary Art of the Western Hemisphere: A Collection of the IBM Corporation Representing the Latin American Countries, Newfoundland and the Province of Canada, the United States and Its Possessions, took place in 194I at the Montreal Museum of Fine Arts. A more structured exhibition on Mexican art called Mexican Art Today followed in 1943 and toured to the National Gallery of Canada in Ottawa, the Montreal Museum of Fine Arts, and the Art Gallery of Ontario. Sarah E. K. Smith situates this 1943 exhibition of Mexican art in Canada, and the 1946 and 1960-6I exhibitions that followed, as early examples

55. Ramírez, "Brokering Identities," 2I.

56. Mari Carmen Ramírez, "Beyond 'the Fantastic': Framing Identity in US Exhibitions of Latin American Art," Art Journal 51, no. 4 (1992): 67-68. 
of cultural diplomacy, key to building broader relationships between Canada and Mexico, and by extension Latin America more broadly. Beyond diplomatic tactics, these cultural exchanges also supported the creation "of an image of Mexico, or of different Mexicos, in Canada, indicating what sort of nation the Mexican state was interested in promoting abroad, as well as what representation of Mexico the Canadian public perceived." ${ }^{57}$ The title of a 1955 exhibition at the National Gallery of Canada is revealing of other countries also engaged in cultural diplomacy: The Embassy of Peru Presents the Art of Peru: Pre-Columbian, Colonial, XIX Century, and Modern.

Meanwhile, the Art Gallery of Greater Victoria was likewise active early on in organizing special Latin American art exhibitions despite having fewer artifacts in its own collection. These exhibitions, organized regularly from 1953 to 1981, covered a remarkable variety of topics, from the Taller de Gráfica Popular (1953) to Inca pottery (1954), Brazilian graphics (1955), Spanish colonial art (1963), and Bolivian textiles (198I), to name just a few. This can be attributed to how the gallery collected and exhibited very broadly in the beginning, capitalizing on early board members' and donors' collections and connections to Central and South America. More recently, the venue has reengaged with artists from Latin America as part of a more structured program plan..$^{58}$

Since the mid-1990s the Winnipeg Art Gallery (WAG) has been a site for activity around Latin American art, as evidenced by the curatorial residency undertaken by the Brazilian curator Ivo Mesquita, which led to an exhibition of art produced since the I980s in Brazil, Mexico, Argentina, Venezuela, Cuba, and Chile under the banner Cartographies: I4 Artists from Latin America. This critically acclaimed show toured to the National Gallery in Ottawa, then on to other sites such as the Bronx Museum in New York, various cities throughout Latin America, and the Madrid gallery La Caixa. The display would eventually win for the Winnipeg Art Gallery the International Council of Museums Award for best exhibition. ${ }^{59}$

57. Sarah E. K. Smith, "Exhibiting Mexican Art in Canada: Histories of Cultural Exchange and Diplomacy in the Mid-Twentieth Century," in Latin America Made in Canada, forthcoming.

58. Stephen Topfer, email communication with author, June 3, 2017

59. On this exhibition see "Celebrating a Century," Winnipeg Art Gallery, http://www.wagroo.ca/test/date:1993\#story. I thank Sarah E. K. Smith for bringing this case to my attention. She is currently writing about the WAG's institutional support for Latin American art through a
Sarah E. K. Smith argues that NAFTA amplified cultural exchanges in North America as a strategy in the service of political and economic ties toward building public confidence in the region's new economic integration. ${ }^{60}$ These cultural exchanges, spurred by globalization trends, which took form (among other ways) in such practices as exhibitions of Mexican art in Canada, reveal a developing infatuation toward Latin American exhibitions in Canada among major national museums as well as smaller galleries, university museums, and specialized venues. Recently there has been an initiative among Canadian cultural institutions to host online exhibitions, and some of them have included Latin American visual material, such as Panoramas: The North American Landscape in Art (2008) and Perspectives: Women Artists in North America (2009). ${ }^{61}$ A collaborative exhibition between the Textile Museum of Canada and the Gardiner Museum on Pre-Columbian cloth and clay included an online component. The Canadian Museum of History also developed an online exhibition on the Mayan civilization. All of these examples provide teachers' resources adapted for students at different grade levels.

Sur Gallery in Toronto must be mentioned in this context: it is Canada's only gallery space dedicated to showcasing and promoting contemporary Latin American artistic practices. ${ }^{62}$ Sur Gallery is connected with Latin American-Canadian Art Projects (LACAP), a Toronto-based nonprofit organization promoting Latin American art in Canada with an emphasis on artistic excellence, critically engaged creative practices, and hemispheric networks of exchange. ${ }^{63}$ Similar in spirit would be Espacio México, the cultural entity of the Mexican consulate in Montreal, which also serves as an art gallery curating exhibitions related to the Latinx Canadian community. ${ }^{64}$

curatorial residency. Sarah E. K. Smith, email communication with author, August 29, 2017.

6o. Sarah E. K. Smith, "Visualizing the 'New' North American Landscape," in Negotiations in a Vacant Lot: Studying the Visual in Canada, ed. Lynda Jessup, Erin Morton, and Kirsty Robertson (Montreal: McGillQueen's University Press, 2014), I30-49; Sarah E. K. Smith, "Cross-Border Identifications and Dislocations: Visual Art and the Construction of Identity in North America," in Parallel Encounters: Culture at the Canada-US Border, ed. D. F. Stirrup and Gillian Roberts (Waterloo: Wilfred Laurier University Press, 2013), 187-205.

6I. These online exhibitions were formerly hosted at http://www.virtualmuseum.ca/, but seem to have been removed.

62. "Mandate," Sur Gallery, http://surgallery.ca.

63. "Mandate," Latin American-Canadian Art Projects, http://lacap.ca.

64. See https://consulmex.sre.gob.mx/montreal/index.php/en/ espacio-mexico-eng. 
The Darling Foundry, through the Conseil des arts de Montréal, has established since 2008 some artist residencies, a program that is now fully devoted to Latin American artists and curators. ${ }^{65}$ Created in 2009 , also in Montreal, LatinArte is a nonprofit, multidisciplinary cultural organization that coordinates activities and events where the public can enjoy contemporary works by local artists of Latin American descent, or other professional artists in Quebec whose work is inspired by Latin American culture. ${ }^{66}$

Alongside the aforementioned organizations that encourage intercultural collaborations about Latin American art, a number of initiatives complement the work of museums and bridge interdisciplinary efforts at studying and teaching Latin American art. For example, the RÉLAM (Réseau d'études latino-américaines de Montréal/Latin American Studies Network of Montreal) was established in 2014 to enable research and collaboration among professors and graduate students at Montreal universities (Concordia, McGill, Université de Montréal, Université du Québec à Montréal) who work on Latin American topics. ${ }^{67}$ Another example is RÉAL (Réseau d'études sur l'amérique latine), a research unit at the Université de Montréal whose main objective is to promote research, teaching, and outreach activities on Latin America. ${ }^{68}$ Despite not having a strong presence of humanities scholars or professional art historians in any of the research groups, it has nonetheless supported art exhibitions. Networks such as LACAP, LatinArte, RÉLAM, and RÉAL exist in a gray area between museums and academia and fulfill not just an intercultural function but also an interdisciplinary and interinstitutional one.

65. See http://fonderiedarling.org/en/residencyamericas.html. I thank Analays Álvarez Hernandez for this information.

66. See http://latinarte.ca/?lang=en. Mariza Rosales Argonza, an independent artist, curator, and researcher from Mexico based in Montreal, organized an exhibition in 2010 as part of her postdoctoral fellowship at the Centre interuniversitaire d'études sur les lettres, les arts et les traditions (CÉLAT). Territoires autonomes: lindépendance d'une culture explored the works of Latinx Québécois artists in the context of the bicentennial of Mexican independence. It was the first time LatinArte collaborated with the Maison de la culture Villeray-Saint-Michel-Parc Extension, in the context of the festival LatinArte. The event was so successful that it was afterward included in the annual program of the LatinArte festival. Mariza Rosales Argonza, email communication with author, August 29, 2017.

67. See http://relam.org/relam/?page_id=9.

68. See http://cerium.umontreal.ca/en/research/research-units/ research-network-on-latin-america-real/. Both RÉLAM and RÉAL are affiliated with the Centre d'études et de recherches internationales de l'Université de Montréal (CÉRIUM).

\section{LATIN AMERICAN ART IN CANADIAN UNIVERSITIES}

In this section, I mean to address key figures in the fieldthe "pioneers" of Latin American art in Canada. The current generation of established and junior scholars is also important, as they are fundamental to preparing tomorrow's generation and ensuring continuity of Latin American art studies in Canada. Graduate students' voices were also taken into account, as they offer yet another perspective on the field. Some information was retrieved from departmental web pages, and some was obtained through a questionnaire I circulated in summer 2017 to colleagues working in Latin American art, visual culture, and architecture in Canadian universities. ${ }^{69}$ The questionnaire addressed different issues relevant to scholars and helped me get a sense of: their initial contact with the subject area; how they teach Latin American art and visual culture; what sorts of, and how many, graduate students they supervise; the relations they perceive with other disciplines; resources offered at their home institutions, such as slide libraries and library holdings of books and scholarly journals; resistance, advantages, and anecdotes from working in the field of Latin American art in Canada; if they believe this is a growing subject area in Canada; whether they see a connection between geopolitical issues in Canada and Latin American art; if they receive funding from Canadian agencies for their research; whether or not they present their findings at scholarly associations in Canada and/or publish in Canada; and their involvement, if any, with Canadian museums and art galleries in relation to Latin American art. This section draws from this data.

Latin American art as a field of study in Canadian universities was established in the I970s. The earliest university appointments were in Pre-Columbian art: three scholars were hired around the same time at British Columbia universities to cover that subfield. This situation might be related to the American situation of scholarship from the I940s to the 1970s, when a post-World War II generation of scholars demonstrated interest in previously under-researched phenomena in art history. ${ }^{70}$ All of these pioneers

69. I received clearance from the Ethics Board of Western University with the study title "Latin American Art in Canada," file number 109435.

70. Edward Sullivan, "Portuguese Art History: A View from North America," Journal of Art Historiography I6 (2017): 2. See also the special number on "Theory, Method, and the Future of Pre-Columbian Art History," ed. Cecelia F. Klein, Journal of Art Historiography 7 (20I2); Cecelia F. Klein, "Not Like Us and All the Same: Pre-Columbian Art History and the 
of teaching Latin American art in Canada obtained their degrees from US universities.

The first professor of Latin American art in Canada was Alan R. Sawyer, an art historian, curator, museum director, collector, professor, author, and consultant who specialized primarily in Pre-Columbian art but later in his career developed an interest in Northwest Coast art. ${ }^{71}$ He was a professor of art history at the University of British Columbia (UBC) from 1974 to 1984 . Avid collectors, he and his wife possessed Pre-Columbian and Northwest Coast pieces that were often examined by researchers and exhibited across North America. Sawyer's interest in Mayan art began while he was completing his first graduate degree at the School of the Museum of Fine Arts in Boston. He obtained a second graduate degree in art history from Harvard University in 1949. ${ }^{72} \mathrm{He}$ was awarded an honorary doctorate by his alma mater, Bates College, in 1969. Prior to joining UBC Sawyer held many appointments in the United States, where he taught a variety of courses in art and archaeology and was involved with many museums. He coordinated different exhibitions on "primitive art," making a special contribution to Pre-Columbian art.

Marvin S. Cohodas came to UBC in 1976 after earning his $\mathrm{PhD}$ from Columbia University. Until his retirement in 2015, he was an important figure because his expertise in Mesoamerican arts complemented Sawyer's focus on the pre-Hispanic Andean arts of South America. ${ }^{73}$ Cohodas also took over the teaching of a course on Indigenous arts of North America that Sawyer developed before his retirement. (Charlotte Townsend-Gault was hired a few years after to cover specifically the field of Canadian Indigenous art. This early, close relation, but also distinction, between Indigenous arts of North America versus Latin America is interesting to note.) Rounding out the trio of initial appointments to Latin American art faculty positions in British Columbia is Charles R. Wicke, who taught Pre-Columbian art at the University of Victoria from 1979 to $1987 .^{74} \mathrm{~W}$ icke received his $\mathrm{PhD}$ from the University of

Construction of the Nonwest," RES: Anthropology and Aesthetics 42 (2002): I3I-38.

71. See Jennifer Vanderfluit, ed., Alan R. Sawyer Fonds (Vancouver: University of British Columbia, 2015-16), https://www.library.ubc.ca/ archives/u_arch/sawyer.pdf.

72. "Alan R. Sawyer," Museum of Anthropology Archives, http://atom. moa.ubc.ca/index.php/alan-r-sawyer.

73. Cohodas questionnaire response.

74. "Charles R(obinson) Wicke," Contemporary Authors Online, Literature Resource Center (Detroit: Gale, 2002), http://go.galegroup.com/
Arizona in 1965 and spent considerable time in Mexico, where he not only undertook graduate studies at three institutions (Mexico City College, 1954; Escuela Nacional de Antropología e Historia, 1955-56; and Universidad Nacional Autónoma de México, 1958-60) but also held different teaching positions in anthropology prior to joining the art history department at the University of Victoria.

While these figures were instrumental in bringing initial attention to the field, a number of other scholars continue to do important work on Latin American art in British Columbia. For example, Serge Guilbaut's appointment to the art history department at UBC after graduating from UCLA in 1979 is notable, since he identifies himself not as a specialist or teacher of Latin American modern and contemporary art but as "a helper in making people aware that not only Paris and New York had a modern culture."75 Guilbaut was involved with Latin America experts such as art critic and curator Olivier Debroise, who invited him to Mexico City to discuss contemporary art in his gallery, Curare, and its eponymous magazine. Guilbaut was subsequently inspired to organize a series of seminars and discussions to show students that countries from Latin America have contemporary and modern histories, as well as many other events at UBC that opened a dialogue on twentiethcentury art between North and Latin America. ${ }^{76}$

Among those with whom Guilbaut shared his interest in Latin American art is Rita Eder, a researcher and professor at Universidad Nacional Autónoma de México's Instituto de Investigaciones Estéticas who held a Canada research chair in contemporary Latin American art at $\mathrm{UBC}$ in $2003-4 \cdot{ }^{77}$ Eder has received several distinctions and awards for her extensive research and publications in the fields of modern and contemporary Mexican art and Latin American art. ${ }^{78}$ Eder also taught undergraduate and graduate courses on Latin American art while at UBC

ps/i. do?p=LitRC\&u=lond95336\&id $=$ GALE $\% 7$ CHroooro $8895 \& v=2.1 \&$ it $=$ r\&sid $=$ LitRC\&asid $=$ ra99 6 eaf.

75. Email communication with author, June 12, 2017.

76. For example the symposia "Threatened Identities: Self-Imagining Mexico and Canada" (1992, with John O'Brian); "The Exotic Gaze and the Mexican Appeal: Views for North America 1930-1960" (1995); "Solitudes and Globalization: Post-World War II Art and Culture across the Americas" (2006, with William Wood and Kim Phillips); "Breathless Days: 1959-1960" (2009, with John O'Brian and Carla Benzan); "Las Americas" (2009, Canada, USA, and Latin America). From the university web page http://ahva.ubc.ca/ persons/serge-guilbaut/.

77. I thank Evonne Levy and Marvin Cohodas for this information.

78. From the university web page, http://www.esteticas.unam.mx/ rita_eder. 
and found the students quite receptive to knowing more about this particular field of study. ${ }^{79}$ Some of these students would eventually pursue professional art careers of their own, such as the Canadian Colombian writer and curator Juan A. Gaitán, who went on to be appointed director of a contemporary Latin American art institution after training as an artist and art historian at both UBC and the Emily Carr Institute of Art and Design in Vancouver. ${ }^{80}$ Eder and Guilbaut, alongside a rather large group of experts, have participated in projects focused on Latin America financed by Getty grant programs. Eder has established interdisciplinary partnerships, notably with UBC history professor William French, with whom she embarked on a collaborative project in Oaxaca in which they taught an intensive course on Mexican art.

Although there are currently no faculty members devoted full time to teaching Latin American art at UBC's Department of Art History, Visual Art, and Theory, the university nurtures a fruitful relationship with Latin American art through its Museum of Anthropology (MOA). Anthony Shelton, who has directed the MOA since 2004, has a special research interest in Latin American, Iberian, and African visual cultures as well as the history of collecting and critical museology. ${ }^{81}$ Finally, social anthropologist Nuno Porto holds a faculty appointment at UBC's Department of Art History, Visual Art, and Theory while also serving as MOA's curator for Africa and Latin America since $2012 .{ }^{82}$ Informed by his fieldwork in rural Portugal, Porto bridges his interests in religious experience and visual and material culture. He has curated exhibitions that explore transformations of Indigenous knowledge into national legislation in order to bring about new ways of understanding Amazonian material culture. ${ }^{83}$

On the opposite side of Canada, interesting things were also happening in the r970s. While there was no interest from the University of Western Ontario's Visual Arts

79. Email communication with author, September 3, 2017.

80. "Juan A. Gaitan Appointed Curator of the 8th Berlin Biennale for Contemporary Art," http://www.forumpermanente.org/noticias/2012/juana-gaitan-appointed-curator-of-the-8th-berlin-biennale-20I4. Gaitán currently is the director of the Museo Rufino Tamayo, a key art institution in Mexico City.

81. From the university web page, http://ahva.ubc.ca/persons/ anthony-shelton/.

82. From the university web page, accessed August 6, 2017 and no longer extant, https://extendedlearning.ubc.ca/about-us/our-instructors/ nuno-porto.

83. From the university web page, https://ubc.academia.edu/ NunoPorto.
Department to create a position in Latin American art studies during this time, a classics specialist, Mark Cameron, developed a personal interest in Pre-Columbian art, and on his own initiative built a slide collection between the late 1970 and early 1980 os based on his travels throughout Mesoamerica, which his colleagues in anthropology occasionally used. Cameron, who specialized in Minoan frescoes, also taught a course on Mayan and Pre-Columbian art at least once at Western. Upon his untimely death in 1984 , all of Cameron's slides of Mesoamerican art and architecture were retained in the slide library, which Western has since digitized and added to the online database of the Visual Arts Department. ${ }^{84}$ It is interesting to see that Pre-Columbian interest developed from a specialist in classical art, especially around the same time when British Columbia universities were hiring specialists specifically to teach in this field.

Meanwhile, in Montreal a course on Latin American art appeared in McGill University's 1970-7I university calendar, but Latin American art studies itself has not had a continuous presence in the department of art history since. ${ }^{85}$ Concurrently, Luis de Moura Sobral introduced a course on Latin American baroque art in the early 1980 s at the Université de Montréal. A specialist in Portuguese baroque painting, Sobral bridged his knowledge of the situation in Brazil with Latin American art. Soon after, Yves Deschamps inaugurated and taught a course on Pre-Columbian art and architecture for many years at the same university. While a course on modern and contemporary Latin American art wasn't offered until 2009, the Université de Montréal remains to my knowledge the sole Canadian institution that regularly covers such a vast array of Latin American topics despite the absence of a full-time or tenured faculty member specializing in the field.

It wasn't until the 1990 s that Latin American art studies really experienced sustained growth, to which a wave of faculty appointments attests. This situation might be explained by increased globalization during that decade, as Sarah E. K. Smith argues when she talks about the amplification of cultural exchanges stimulated by NAFTA. Among these notable appointees was Desmond Rochfort, who served from 1990 to 1999 as a specialist in Mexican art

84. I wish to thank Kathryn Brush, Peggy Ellis, John Hatch, Kim Neufeld, Mike Spence, and David Wilson, who helped me reconstruct the story of this slide collection.

85. I thank Evonne Levy for the calendar information; Angela Vanhaelen, email communication with author, June I6, 2017. 
in the University of Alberta's department of art history. ${ }^{86}$ In southwestern Ontario, Dot Tuer redesigned and taught the introductory art survey course at the Ontario College of Art and Design in 1992 based on her cross-cultural expertise in modern and contemporary art. ${ }^{87}$ Throughout her research and teaching, Tuer has touched on the art of the Americas with a specific expertise in new media, photography, and performance as well as other topics of interest such as Latin American colonial history, postcolonial theory, and cultural theory. ${ }^{88}$ Another appointment during this time was that of artist and curator Patrick Mahon, who joined Western University in 1995 as a professor of visual arts; he became involved in Latin American art studies largely through its intersection with his own interests and his graduate supervision duties. ${ }^{89}$ Finally, the arrival of Susan Douglas at the University of Guelph in 1998 opened up opportunities for teaching contemporary Latin American art history and theory given her specialization in the area. ${ }^{90}$

The first decade of the 2000 s was also characterized by a steady wave of interest in Latin American art and visual culture among Canadian universities. For example, the arrival at the Université du Québec à Montréal (UQAM) of trained archaeologist Daniel Arsenault in 2002 opened up opportunities for undergraduate and graduate teaching of courses in Indigenous arts, Pre-Columbian arts and architecture, and issues of heritage and conservation. ${ }^{91}$ His research on

86. Rochfort initially trained as a painter at the Byam Shaw School of Art in London before graduating with an MFA from the Royal Academy of Arts in London. He earned his $\mathrm{PhD}$ in art history from the Royal College of Art in London. Rochfort was president of the Alberta College of Art and Design in 1999, and later was head of the School of Fine Arts at the University of Canterbury in Christchurch, New Zealand. Known as one of Britain's leading public mural artists, he was dean of the Faculty of Fine Arts at the University of Lethbrige from 2009 to 2013, and he retired in 2016. Trevor Kenney, "U of L Welcomes New Dean of Fine Arts and University Librarian," University of Lethbrige UNews, https://www.uleth.ca/unews/article/u-lwelcomes-new-dean-fine-arts-and-university-librarian; Trevor Kenney, “Jurkowski Named Dean of Faculty of Fine Arts," University of Lethbrige UNews, https://www.uleth.ca/unews/article/jurkowski-named-dean-faculty-fine-arts; [no author], "Annual Long Service Awards and Retirement Recognition Ceremony," University of Lethbridge Human Resources, http://www.uleth.ca/hr/annual-long-service-awards-and-retirement-recognitionceremony-2016.

87. Tuer questionnaire response.

88. From the university web page, https://www2.ocadu.ca/bio/ dot-tuer.

89. Mahon questionnaire response.

90. From the university web page, https://www.uoguelph.ca/arts/ sofam/people/susan-douglas.

91. From the university web page, http://www.museologie.uqam.ca/ Page/arsenault_daniel.aspx.
Indigenous rock art in northern Canada brought him to wider interests, such as rock art in Australia, Italy, the United States, the Antilles, and Brazil. Arsenault's sudden death in 2016 left these research areas uncovered..$^{22}$ Meanwhile, in 2004 Dan Russek joined the department of Hispanic and Italian studies at the University of Victoria; he specializes in modern and contemporary Latin American literature and visual arts, specifically how these link with literature, media, urban studies, and aesthetics. ${ }^{93}$ Another important figure is Betsy Boone, a specialist in nineteenth-century art and visual culture of the United States, Spain, and Latin America, who arrived as the chair of the University of Alberta's Department of Art and Design in 2006. ${ }^{94}$ In 2007, Maria del Carmen Suescun Pozas brought her interdisciplinary training as a visual artist, art historian, and historian to the History department at Brock University, where she is currently the specialist in Latin American history. ${ }^{95}$ At Western University, the department of Visual Arts appointed Cody Barteet in 2008 as an early modernist with a specialization in Europe and the Americas. Although his research focuses almost exclusively on Latin American art, specifically the contact period in the Yucatán peninsula, most of his teaching has been on the Renaissance and baroque periods aside from a second-year Pre-Columbian course that he teaches as part of his course rotation. ${ }^{96}$ After a postdoctoral fellowship at the Université de Montréal, Alena Robin arrived at Western University in 2009 with an appointment as the visual arts specialist in the Hispanic Studies program of the Department of Modern Languages and Literatures. Originally from Quebec, she did her graduate studies in art history at the Universidad Nacional Autónoma de México. ${ }^{97}$

The arrival of Gauvin Alexander Bailey at Queen's University in 20I for the Alfred and Isabel Bader Chair is significant because while the Bader Chair has traditionally been a baroque art position that attracts specialists on Caravaggio or similar southern European artists, Bailey embarks on a much wider area in his teaching and research, given his globalized perspective on the early modern world. ${ }^{98}$ As such, he covers such topics as late

92. Dominic Hardy, email communication with author, August 25, 2017. 93. Russek questionnaire response.

94. Boone questionnaire response.

95. From the university web page, https://brocku.ca/humanities/history/faculty-staff/maria-del-carmen-suescun-pozas/.

96. Barteet questionnaire response.

97. https://www.uwo.ca/modlang/about_us/robin.html.

98. Gauvin Alexander Bailey, email communication with author, August 9, 2017. 
Renaissance, baroque, and rococo art and architecture in France, Italy, Central Europe, and Iberia, as well as their international diffusion in Latin America, Asia, and Africa. ${ }^{99}$ Given his diverse research background, Bailey is probably the most visible Canadian Latin American art historian on the international scene at the moment. On the West Coast, artist and art historian Gabriela AcevesSepúlveda was hired in 2015 in the School of Interactive Arts and Technology at Simon Fraser University in Vancouver. She specializes on feminist media in Latin America, global networks of artistic exchange, art and activism, and the histories of immersive technologies in the Global South. ${ }^{100}$ Finally, in 2018 McGill University hired Camila Maroja, who works with modern and contemporary art and visual culture, with an emphasis on Latin America and transnational exchanges. ${ }^{101} \mathrm{Her}$ research focuses on exhibition histories, cultural interchanges between South and North America, the ways in which artists negotiate and localize their production in a globalized world, decolonial methodologies, and local avant-gardes. McGill University thus brings to a welcome end a situation in which all four Montreal universities were without a Latin American specialist in their art history departments.

Some departments in Canadian universities showed interest in Pre-Columbian art specialists starting with the first appointments to the field in the 1970s. Courses on Latin American art from various historical periods are currently being taught to some extent in many Canadian universities, and the number of students enrolled in these courses reveals that there exists a definite interest in the field. At the graduate level, numerous theses on Latin American art are being defended in Canadian universities.

As shown in appendix 2, I have identified seventy-nine theses that have been defended in Canada regarding Latin American art and visual culture, including theses from departments other than art history that take an interdisciplinary approach to Latin American art and visual culture. Going back chronologically has been a challenge, as departmental listings tend to include only the most recent dissertations. The earliest one I could trace is from 1987; it

99. From the university web page, http://www.queensu.ca/art/ bailey-gauvin-alexander.

I0०. From the university web page, https://www.sfu.ca/siat/people/ research-faculty/gabriela-aceves-sepulveda.html.

Ior. From the university web page, https://www.mcgill.ca/ahcs/people-contacts/faculty/camila-maroja. does not necessarily mean that it was the first. Some preliminary data: forty-two master's theses and thirty-seven $\mathrm{PhD}$ dissertations were identified. Most of the topics consider twentieth-century art (fifty-two), followed by Pre-Columbian (thirteen), early modern (eleven), and nineteenth century (three). Canada being a bilingual country, this is also reflected in the languages used: English (fifty-four) and French (eighteen). The remaining seven, written in Spanish, were mostly from languages and literatures departments. The result of this inquiry reflects the Canadian geography mentioned elsewhere in this essay: Latin American art in Canadian universities manifests through its theses mostly in urban centers that are also vibrant artistic centers. It is also connected to the fact that there is, or was, a specialist in or closely related to the field supervising the graduate student. In British Columbia, only at the University of British Columbia was there a highly significant number of theses defended in relation to Latin American art and visual culture (ten). In Ontario, the presence of specialists is scattered among different universities and this situation is reflected in the data gathered: Queen's University (eight), Western University (seven), the University of Toronto (six), Carleton University (two), and Ryerson University (two). Quebec has the highest number of dissertations related to Latin American art: Université de Montréal (eleven), Université du Québec à Montréal (nine), Concordia University (eight), and McGill University (eight). This information is quite valuable, since currently there is only one specialist, in a tenure-track position, related to Latin American art in Quebec, but it definitely shows that there has been a steady interest in studying art topics from this region.

The history of appointments in the field at the university level seems to evidence the dynamism of Latin American art studies in Canadian universities. However, many graduate students consulted in this research voiced their concerns about the reduced number of courses offered, as well as difficulties in finding a supervisor who could orient them properly through their graduate studies. It is a situation I personally confronted when I first decided to leave Canada to complete my graduate degrees in Mexico twenty years ago. Hearing current graduate students in Canada comment on similar challenges in working on Latin American art in the country reveals that things have not changed much. Many positions in Latin American art tend to disappear when the scholars who previously offered their expertise retire. Some of the specialized courses that existed as 
early initiatives representing Latin American art in art history departments are still officially offered, but mostly by adjunct and/or part-time faculty members. The current generation of full-time, tenure-track positions does not include many with appointments exclusive to Latin American art. Having a Latin American art scholar in an art history department in Canada is still an exception.

Latin American studies programs across the country rely heavily on the contributions of specialists from other departments. Hence Latin American studies students in Canadian universities may receive very limited (if any) exposure to Latin American art during their formative years unless there is a specialized faculty member in the art history department. While departments of modern languages or Hispanic studies programs across Canada try to relieve this by looking to various faculty members to offer "interartistic" or "interdisciplinary" approaches to Latin American art, a number of these usually begin from a primarily literary standpoint that analyzes artworks from fundamentally non-art-historical perspectives and methodologies.

The case of Montreal is particularly regrettable. Of the four research universities there with art history programs (Concordia University, McGill University, Université de Montréal, and Université du Québec à Montréal), three of them collaborate with Université Laval in Quebec City in their doctoral programs. It is worrisome that there is currently only one faculty member specializing in Latin American art to teach and supervise all of the relevant master's and doctoral candidates despite the clear interest in the field among graduate students. Concurrently, while there are two Latin American faculty members (Ricardo Castro and Alberto Pérez-Gómez) at McGill University's School of Architecture who are also professional architects, neither of them specializes in Latin American architecture per se. ${ }^{102}$

The precarity of Latin American art studies in Canada is also reflected in how recent graduates in the field struggle to find stable appointments and must resort to parttime employment or leave the field altogether. I am not sure at this point if the paucity of academic positions in Latin American art in Canada is a sign of a lack of interest on the part of department administrations, or merely a reflection of the broader crises experienced by universities

I02. For example, although he has supervised two PhD dissertations that focus on Mexican architecture, Pérez Gómez is mainly interested in the history and theory of early modern European architecture. Alberto Pérez Gómez, email communication with author, May 5, 2017. manifesting in fewer tenure-track positions outside of STEM fields. Maybe it is a combination of both. This situation is, in any case, troubling: since adjunct and parttime faculty do not enjoy the same stability as full-time and tenured members, most of them cannot supervise graduate students and lack institutional support for research. These issues in turn endanger the formation of the next generation and may thus disrupt the presence and continuity of Latin American art studies in Canada.

\section{RECOMMENDATIONS FOR FUTURE STEPS}

This assessment of the presence of Latin American art in Canadian museums and universities might serve as a reflection for new and broader approaches to the study of Latin American art history. Revisiting the cultural impact of Latin American art in Canada, a multicultural country with a growing Latin American population, should also give an indication of the importance of reinscribing the tradition within a reconfigured hierarchy of art history. If the discipline of art history in Canada truly aspires to go beyond the established canon and address a more complete picture of the field of art history, greater efforts are needed among stakeholders to rethink the dominant Eurocentric conception of art that currently underprivileges Latin American art. As already discussed in this paper, Pre-Columbian art and architecture are as valuable to art history as ancient Greek and Roman art. Latin American art from the early modern period can also clue us in to the historical period of intense contact with other latitudes and longitudes, since we cannot fully understand the globalized world without first taking into account the cultural networks and commodity exchanges between Europe, America, Asia, and Africa. Finally, studying Latin American art from the modern and contemporary periods gives credibility to artistic capitals such as Buenos Aires, Havana, Mexico City, and São Paulo, to name only a few. Employing new theoretical and methodological approaches such as gender, postcolonial, conservation, and materiality studies can help facilitate a more inclusive vision that embraces artistic traditions that have not been canonically recognized. Recently, searches for positions on cultural transfers and globalized contemporary art were advertised in Canadian universities. Although not clearly having a Latin American art component, this might open the possibility of making the discipline more inclusive. 
This paper has demonstrated the abundance and richness of Latin American art and visual culture in Canadian public collections. However, very little has been written regarding the history of these collections, the extent of museums' Latin American collections, their current strategic plans and acquisition programs, et cetera. While some museums have a fair amount of information about their Latin American collections on their websites and were very generous in answering queries related to this research, many others have not yet fully studied or engaged with their own objects. There is a story still waiting to be told about how these collections were built, and how Canadian museums have employed their curatorial practices to fully contextualize their collections in exhibitions. Only after Canadian collections of Latin American art have been studied individually can a dialogue arise among them. Some potential initiatives toward this end are online collaborative exhibition projects among Canadian museums to showcase highlights of their Latin American collections, or touring exhibitions that could cross Canada and introduce new perspectives on existing museum collections.

This spirit of collaboration can be further extended to improving interinstitutional relations among museums and universities. Given the extent to which Canadian museums had been active in collecting and exhibiting Latin American art, their work at exposing Latin American art to the Canadian public has surpassed the canon explored in our universities. I believe that the museum initiatives should be emphasized and celebrated in regard to the many ways they have exposed Canadian audiences to Latin American art, whether through their permanent collections, temporary exhibitions, catalogue publications, or conferences.

Meanwhile, there should be better collaboration between museums and universities in relation to Latin American art, because both public and private collections of Latin American art in Canada need to be explored, studied, and shared with the public. All Latin American art objects-whether they are part of collections in storage, exhibited in the permanent rooms, made by Latinx artists in their studios in Canada, or displayed in universities, smaller galleries, or curatorial residencies-should be engaged with by active participants in this adventure of Latin American art in Canada. No matter how fascinating and necessary it is to go abroad to study Latin American art in its original context, these explorations can start in Canada. In this sense, as mentioned previously, an online exhibition of Canadian collections of Latin American art can be a great tool to expose students to this heritage.

There is also a need to leverage the current global migratory situation that has generated new and different artistic expressions. This is another timely issue: the urgency of addressing a generation of artists who were born in Latin America but migrated at some point in their lives to Canada, and who may have interesting new perspectives. Some initiatives have already begun toward this end, but many more are needed. The 2016 exhibition TransAMERICAS. A Sign, a Situation, a Concept, curated by Dianne Pearce and Cassandra Getty at Museum London, was an important step toward that reflection. In Quebec, Mariza Rosales Argonza, an independent researcher, artist, and curator, has addressed this question in different exhibitions and publications. ${ }^{103}$ Nuria Carton de Grammont and Tatiana Navallo have started studying latino-québécois performance. ${ }^{104} \mathrm{In}$ fall 2018 Toronto's Sur Gallery hosted The Recipe, an exhibition curated by Analays Álvarez Hernandez and Daymi Coll Padilla related to the topic of Latinx Canadian artists. In an attempt to provide a new understanding of Latin American art practices operating outside of their geographical edges, The Recipe brought together emerging and established artists with Latin American backgrounds who are living and working in Canada. ${ }^{105}$ Furthermore, Canadian artists who express a close affiliation with Latin America in their work need to be part of this conversation. An artist already active in this dialogue is the Québécois René Derouin, who offers an open dialogue on the continental identities of the Americas. Since the mid-r95os he has shown an interest in Pre-Columbian cultures, the aesthetic of the Taller de Gráfica Popular, and Mexican muralism. ${ }^{106}$ Another example is Victor Pimentel and Sebastián Ferrero's recently curated exhibition at Espacio México gallery on the work of Léo Rosshandler, a former curator and assistant

103. Mariza Rosales Argonza, "Angles morts, visions transfrontalières latino-québécoises," in Vues transversales, 127-71. See also Edith-Anne Pageot, "Figure de l'indiscipline. Domingo Cisneros, un parcours artistique atypique," RACAR 42, no. I (2017): 5-21. LACAP has a directory of Latinx artists residing in Canada: http://lacap.ca/directory-of-latinoa-artists/list-ofartists/. The Canadian Association of Hispanists also has such a listing, called "registro creativo": http://www.registrocreativo.ca.

I04. Nuria Carton de Grammont and Tatiana Navallo, "Poétiques du déplacement dans la pratique performative latino-québécoise," in Vues transversales, $173-223$.

I05. Analays Álvarez Hernandez, email communication with author, September 10, 2017. See http://lacap.ca/sur-gallery/exhibition-archives/ the-recipe-making-latin-american-art-in-canada/.

I06. From the artist's website, http://www.renederouin.com/wp/en/. 
director of the Montreal Museum of Fine Arts from 1968 to 1976 , who shared a common love for Mexico with the painter Jean leFebure. ${ }^{107}$

In this project, I have reflected on my personal experience and involvement in the field of Latin American art in Canada with the aim of opening a dialogue with other colleagues in the discipline. While many have shared their experiences, knowledge, frustrations, and promises of being a Latin American art historian in Canada, much more work is needed to bring Latin American art studies into the mainstream of art history and curatorial studies. If the field of Latin American art studies is not properly addressed in our museums and universities, we will miss its important contributions to the general population.

This essay only offers a glimpse into the relevance of further investigating Latin American art and art history in Canada. This survey of the current situation raises several

107. Éric Clément, "Léo Rosshandler et Jean leFebure fêtés par la Mexique," LaPresse (Montreal), February I2, 2017, http://www.lapresse.ca/ arts/arts-visuels/201702/10/0I-5068339-leo-rosshandler-et-jean-lefebure-fetespar-le-mexique.php. questions that can help us start such explorations. A single article cannot fill all the gaps on the history and current state of Latin American art and art history in Canadian museums, galleries, universities, and other cultural institutions. This endeavor would require a substantial research program focusing, for example, on information found in institutional and private archives and several case studies. My objective with this paper is to open the discussion in hopes of providing a more complete history of the field. The full story remains to be written.

\section{ABOUT THE AUTHOR}

Alena Robin -is an associate professor of Hispanic studies at Western University. She researches representations of the Passion in New Spain, the historiography of New Spanish painting, and Latin American art in Canada. She authored Las capillas del Via Crucis de la ciudad de México: arte, patrocinio y sacralización del espacio (Universidad Nacional Autónoma de México, 20I4). 